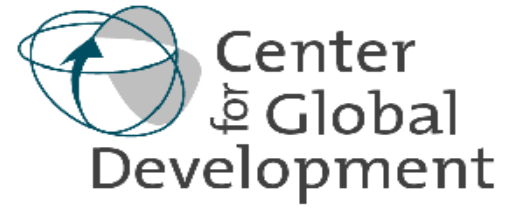

Working Paper Number 159

January 2009

Do Regulatory Reforms Stimulate Investment and Growth?

Evidence from the Doing Business Data, 2003-07

By Benjamin P. Eifert

\begin{abstract}
The role of regulatory barriers in inhibiting entrepreneurship, investment and employment creation is an old topic in economics. This study utilizes a five-year panel of data on regulations and procedures from the World Bank's Doing Business project, along with Arellano-Bond dynamic panel estimators, looking for evidence that regulatory reforms lead to higher aggregate investment rates (roughly, factor demand) or GDP growth conditional on investment rates (roughly, factor productivity). It looks both at individual regulatory indicators and more aggregate measures of the incidence of reforms, finding some evidence of positive impacts of regulatory reforms in countries which are relatively poor (conditional on governance) and relatively well-governed (conditional on income). Relatively poor and relatively well-governed countries grow about 0.4 and 0.2 percentage points faster in the year immediately following one or more reforms, respectively. In both subsets of countries, investment rates accelerate by about 0.6 percentage points in the subsequent year.
\end{abstract}

The Center for Global Development is an independent, nonprofit policy research organization that is dedicated to reducing global poverty and inequality and to making globalization work for the poor. This paper was made possible in part by funding from the Australian Agency for International Development.

Use and dissemination of this Working Paper is encouraged; however, reproduced copies may not be used for commercial purposes. Further usage is permitted under the terms of the Creative Commons License. The views expressed in this paper are those of the author and should not be attributed to the board of directors or funders of the Center for Global Development. 
Benjamin P. Eifert. 2009. "Do Regulatory Reforms Stimulate Investment and Growth? Evidince from the Doing Business Data, 2003-07." CGD Working Paper 159. Washington, D.C.: Center for Global Development.

http://www.cgdev.org/content/publications/detail/1420894 


\title{
Do Regulatory Reforms Stimulate Investment and Growth? \\ Evidence from the Doing Business Data, 2003-07
}

\author{
Benjamin P. Eifert ${ }^{1}$
}

\begin{abstract}
The role of regulatory barriers in inhibiting entrepreneurship, investment and employment creation is an old topic in economics. This study utilizes a five-year panel of data on regulations and procedures from the World Bank's Doing Business project, along with Arellano-Bond dynamic panel estimators, looking for evidence that regulatory reforms lead to higher aggregate investment rates (roughly, factor demand) or GDP growth conditional on investment rates (roughly, factor productivity). It looks both at individual regulatory indicators and more aggregate measures of the incidence of reforms, finding some evidence of positive impacts of regulatory reforms in countries which are relatively poor (conditional on governance) and relatively well-governed (conditional on income). Relatively poor and relatively well-governed countries grow about 0.4 and 0.2 percentage points faster in the year immediately following one or more reforms, respectively. In both subsets of countries, investment rates accelerate by about 0.6 percentage points in the subsequent year.
\end{abstract}

1 Department of Economics, University of California, Berkeley. The author thanks the Center for Global Development (CGD) for funding this research, the Doing Business team for collecting the data and stimulating this research, to Simeon Djankov in particular for constructive feedback, and to seminar participants at CGD, Berkeley and the World Bank for comments and suggestions.

Benjamin P. Eifert. 2009. "Do Regulatory Reforms Stimulate Investment and Growth? Evidince from the Doing Business Data, 2003-07." CGD Working Paper 159. Washington, D.C.: Center for Global Development. http://www.cgdev.org/content/publications/detail/1420894 


\section{Foreword}

I am delighted to sponsor this working paper by Benn Eifert, a doctoral candidate at the University of California-Berkeley, on the response to regulatory reform in developing countries. The paper is commissioned as part of the CGD's ongoing work on weak and fragile states, which is focused on improving the effectiveness of aid in post-conflict interventions. Eifert's paper contributes to this initiative by focusing on the returns to the reform of the regulatory environment-a key determinant of growth of the private sector in fragile and developing economies.

Bilateral and multilateral institutions have directed significant resources toward support for a good business environment, ranking countries by their ability to reduce the time and cost to set up a business and to strengthen property rights and access to credit. Policy interventions to reform the institutional environment-such as reform of courts-are also important in fragile states where ad hoc enforcement of regulations and corruption are real concerns. However, we still do not know a whole lot about the impact of policy reforms related to the business environment undertaken by governments operating in fragile economic environments. This paper contains new and interesting results that draw on five years of regulatory reform across 90 countries. It discusses the characteristics of countries that choose to reform and the results of these reforms. In particular, it contains valuable insights for policymakers and institutions focused on regulatory reform in weak states.

Vijaya Ramachandran

Senior Fellow

Center for Global Development 


\section{Introduction}

Many types of regulations affect firms' decisions: registration and closure procedures, labor laws, import/export licensing, permits for investment projects, zoning regulations, health, safety and environmental standards, carbon pricing schemes and more. Such regulations have many rationales related to market failures or equity considerations. However, economists often point to the way costs and delays imposed by regulations may inhibit investment and employment creation. In advanced industrialized countries, particularly in Europe, many scholars point to rigid labor market regulations as sources of structural long-term unemployment and to sectoral competition policies as contributors to inefficiency and slow economic growth (see Blanchard 2004).

Regulation is not just a developed country issue. In developing countries, burdensome entry and licensing regulations are often exploited by opportunistic government officials to extract payments from firms (Laffont 2005), distorting economic activity and driving many firms to remain in the informal sector where they have little ability to grow and accumulate assets. This may contribute to the stylized fact that dynamic small and medium enterprises are largely absent in many poor countries, while informal micro-enterprises using simple technologies and producing low-value goods and services are ubiquitous. Some argue that streamlining regulations and improving their implementation may be an important part of addressing the widespread lack of opportunities for wage employment and productive entrepreneurship in very poor countries (World Bank, 2005).

This study exploits a relatively new dataset on regulation from Djankov et al $(2002,2003,2004)$, now institutionalized as the World Bank's Doing Business project. Several important variables, including measures of the rigidity of labor laws as well as the procedural burdens facing firms in business registration and closure, contract enforcement, property registration, and import/export, are now available for three to five years across a large set of countries. This allows the use of estimators focusing on economic responses to regulatory reforms within countries over time, rather than on cross-country variation which may be easily polluted by omitted variables.

This study focuses on aggregate investment rates (roughly, factor demand) and GDP growth conditional on investment (roughly, factor productivity) as macroeconomic outcomes. It uses Arellano-Bond dynamic panel estimators to control for unobserved cross-country heterogeneity and correlation between reform timing and the business cycle. The key findings are as follows:

Benjamin P. Eifert. 2009. "Do Regulatory Reforms Stimulate Investment and Growth? Evidince from the Doing Business Data, 2003-07." CGD Working Paper 159. Washington, D.C.: Center for Global Development. http://www.cgdev.org/content/publications/detail/1420894 
1. Over the period 2003-07, regulatory reforms were not concentrated in countries which were also significantly improving their broader policy environments (as measured by International Country Risk Guide ratings) or their political environments (as measured by Freedom House scores). Rather, reform incidence was higher in countries with relatively high initial levels of regulation.

2. There is little or no evidence in the full sample of countries for significant economic responses to changes in the costs and administrative delays associated with business registration, contract enforcement, property registration and import/export procedures, nor to reforms of labor regulations.

3. There is some fairly robust evidence of positive impacts of regulatory reforms in countries which are relatively poor (conditional on governance) and relatively well-governed (conditional on income). These estimated impacts are sizeable but not implausibly large. For instance, the median reform of business registration procedures reduces delays by 10 days, and in relatively well-governed countries is associated with an increase in investment rates of 0.27 percentage points and 0.15 percentage points, respectively.

4. Comparing countries which reform in at least one area in a given year to those which do not, relatively poor and relatively well-governed countries grow significantly faster (conditional on their investment rates) in reform years, about 0.4 and 0.2 percentage points faster, respectively. In both subsets of countries, investment rates accelerate significantly in the year after a reform, by about 0.6 percentage points relative to non-reformers.

Taken together, these results suggest general optimism about the prospects for improved economic performance in reformist countries in the developing world, especially those which are relatively better-governed. This includes China and India, which together contain around half of the world's poor. While we cannot rule out the possibility that governments tend to introduce unobserved economy-boosting measures in the same years as they make specific observed regulatory reforms, biasing the coefficient estimates above upward, one might expect this to lead to a correlation between reform incidence and the trajectory of ICRG scores in particular.

Section 2 provides some theoretical background. Section 3 discusses the existing evidence and the contribution of this study. Section 4 describes the data. Section 5 illustrates patterns in regulatory 
reforms over 2003-07 and then presents the primary results on the macroeconomic impacts of regulations and procedures. Section 6 concludes.

Benjamin P. Eifert. 2009. "Do Regulatory Reforms Stimulate Investment and Growth? Evidince from the Doing Business Data, 2003-07." CGD Working Paper 159. Washington, D.C.: Center for Global Development. http://www.cgdev.org/content/publications/detail/1420894 
This study looks at regulations and procedures around business registration, contract enforcement, property registration, hiring and firing of workers, and import/export transactions. Dynamic economic models of firm behavior illustrate the way that business regulations affect firm behavior over time. Regulations may fix market failures in some cases, enhancing economic efficiency. However, excess costs and delays imposed on firms by regulations and procedures can have negative effects on factor accumulation and factor productivity, either through raising entry barriers for new firms or by increasing variable costs or the costs of adjusting factors of production for existing firms. Useful references include Cooper and Haltiwanger (2006) on investment; Cooper and Willis (2003) and Bentolila and Bertola (1990) on labor adjustment; and Joyanovich (1982), Hopenhayen (1992), and Erickson and Pakes (1998) for dynamic firm models with entry and exit.

Bureaucratic entry barriers reduce the number of firms that enter, and hence invest, hire and produce. Suppose that in each period there are many potential entrants, each observing a noisy signal of its potential productivity. For a given own productivity signal and state of the economy, there is some probability that a potential entrant believes its value will be greater than the entry cost and hence chooses to enter. Lower across-the-board entry costs mean that more firms will enter and accumulate factors of production, increasing aggregate investment and employment. However, as long as entrants' signals of their potential productivity contain some information, the incremental entrants will be disproportionately drawn from the lower portions of the productivity distribution because entry barriers are less likely to deter high-productivity firms. ${ }^{2}$ This moderates the economic impact of entry costs relative to "productivity-unbiased" barriers, like business licenses allocated on a de facto non-economic basis. Entry barriers also influence the competitive environment within a country, affecting the marginal revenue product of capital and labor for incumbent firms and hence their investment and labor absorption decisions. The direction of this effect is ambiguous for any given incumbent firm, as lower entry barriers may imply both less competition in a firm's own market and more competition in upstream and downstream markets.

Exit costs, appear in most models as determining the scrap value of a firm, also affect both the entry and recurring behavior of firms. If it is very costly to liquidate a firm, potential entrants require a

2 If firms' signals are noiseless, then the incremental entrants attracted by a reduction in entry costs all have lower productivity than entrants that would have entered without the reform.

Benjamin P. Eifert. 2009. "Do Regulatory Reforms Stimulate Investment and Growth? Evidince from the Doing Business Data, 2003-07." CGD Working Paper 159. Washington, D.C.: Center for Global Development. http://www.cgdev.org/content/publications/detail/1420894 
better outlook (own productivity signal, state of the economy) in order to be willing to enter, and incumbent firms will more actively avoid projects that have positive expected value but bear some downside risk. Like entry costs, the effect of a reduction in exit costs is potentially a complex function of many changing factors.

Regulations governing hiring and firing affect firms' factor adjustment costs and hence their dynamic demand for labor and capital. Suppose that labor and capital are quasi-fixed factors, such that firms take their current-period stocks as given and make investment, hiring and firing decisions to adjust those stocks over time. The key feature of dynamic models is that adjustment is costly, reflecting frictions which keep firms from instantaneously changing their factor mix and scale of their operations to minimize short-run production costs. With fixed costs of capital and labor adjustment, a firm will let the marginal product of labor and capital fluctuate over some permissible range, adjusting its stocks of labor and capital when changes in the firm's environment drive marginal products out of that range. Higher adjustment costs make firms more conservative about adjusting their factor stocks, as does a more uncertain environment (which raises expected future adjustment); both factors also reduce firms' factor demands and overall value. Asymmetric adjustment costs, e.g. induced by rigid firing regulations, further reduce firms' labor demand. Because labor adjustment costs affect firms' future profits and behavior, they can potentially affect the demand for capital, and similarly capital adjustment costs can affect the demand for labor. As labor and capital adjustment costs affect firm value, they can also influence entry and exit decisions.

The importance of effective contract enforcement is emphasized in the institutional economics literature. Without a legal environment that can reliably and relatively inexpensively enforce business contracts, firms will tend to choose projects and transactions which are simple, short-term and directly monitored. The corresponding reduction in marginal factor products reduces the demand for capital and labor. Certain important markets characterized by complex transactions like financial services and insurance - may only serve large, highly stable businesses or may fail to develop altogether, increasing costs and risk-bearing in the rest of the economy.

One can incorporate the above considerations into a very general dynamic model. The basic result one will find is that the dynamic decisions over capital and labor stocks made by existing firms and potential entrants, and hence the aggregate paths of investment and employment, are potentially affected in negative ways by increases in most types of binding business regulations. This occurs because regulations and procedures increase either firms' variable costs, e.g. delays and costs every 
time a firm ships a container; their factor adjustment costs, e.g. restrictions on the hiring and firing of workers; or their fixed costs, e.g. delays and costs during the business registration process.

It is important to note that different types of red tape have potentially very different effects on firms and economies. Regulations and procedures which increase variable costs are a drag on every unit of output sold, and hence affect firms in proportion to their size and productivity. Those which increase factor adjustment costs also create frictions in the business process that grow with firm size. In contrast, regulations and procedures that increase fixed costs primarily influence whether or not firms enter, and mostly affect the smallest and least profitable firms. A few hundred dollars in registration fees will not deter the large industrial firms that move national aggregates, but might keep micro-entrepreneurs in the informal sector where they have worse access to credit and less secure property rights. Hence reforming regulations and procedures to reduce fixed costs of doing business may be good for poverty reduction but not affect macroeconomic performance, while reforms which reduce firms' variable costs may have more immediate aggregate effects.

The left pane of Figure 1a represents the hypothetical distribution of firm value among potential firms that may choose to enter the economy. The dashed vertical line is the threshold of potential value above which a firm enters. Initially, firms in area $C$ enter and make their investment and hiring decisions, and firms in $\mathrm{A}+\mathrm{B}$ do not enter. Reducing the fixed costs of starting a business shifts that threshold to the left. Many new firms will enter (represented by area B). The right pane illustrates the corresponding density of firm value, which is the density of firms from the left pane weighted by their value. Area B in this pane, the new value created by the reduction in fixed costs, is relatively small because the marginal entrants have relatively low productivity. In contrast, reducing the variable costs of doing business shifts the distribution of firm value to the right (Figure $1 \mathrm{~b}$, left pane), potentially having a larger impact on aggregate productivity (right pane).

Some regulations may enhance economic efficiency. For instance, it is possible for free entry in differentiated products markets to generate more variety than is socially optimal (Dixit \& Stiglitz, 1978). In practice, the dynamic model one will arrive at when incorporating a variety of diverse types of business regulations and market imperfections is enormously complex, and estimating its structural parameters would be quite difficult. The approach taken below is to specify flexible 
reduced-form models, attempting to capture the causal impacts of business regulations on the equilibrium values of economic aggregates. ${ }^{3}$

Of course, there may be socially valuable objectives of regulation to be traded off against potential economic impacts. Labor laws which protect workers against discriminatory hiring or firing practices are a case in point. The empirical objective of this study is not to contradict this point, but rather to investigate the aggregate economic implications of regulation.

Finally, in a global study of regulation there is an important distinction between the de jure and de facto regulatory environments facing firms. In advanced industrialized countries, laws tend to be well enforced. ${ }^{4}$ In developing countries, enforcement of regulations varies widely, and is often subject to significant discretion of the government officials in question. It may well be that in some countries the official regulations imply a very burdensome entry process, but in fact a bit of creativity and a few bribes make the process go quite smoothly and quickly. In others, it may be that the laws are relatively permissive but the process of dealing with corrupt officials along the way makes the process quite burdensome. This issue is addressed in more detail in the following sections.

${ }^{3}$ In general, the impact of reforms is potentially a complicated, nonlinear function of the current level of regulations, the distribution of potential entrant productivity and the state and structure of the economy. It is important to keep in mind the potentially complex relationships at work, but in the current study, data considerations limit the use of nonlinearities.

${ }^{4}$ Not universally; e.g. an estimated two-thirds of agricultural workers in California are undocumented. 
Figure 1a. Reducing the fixed costs of doing business (e.g. registration procedures)

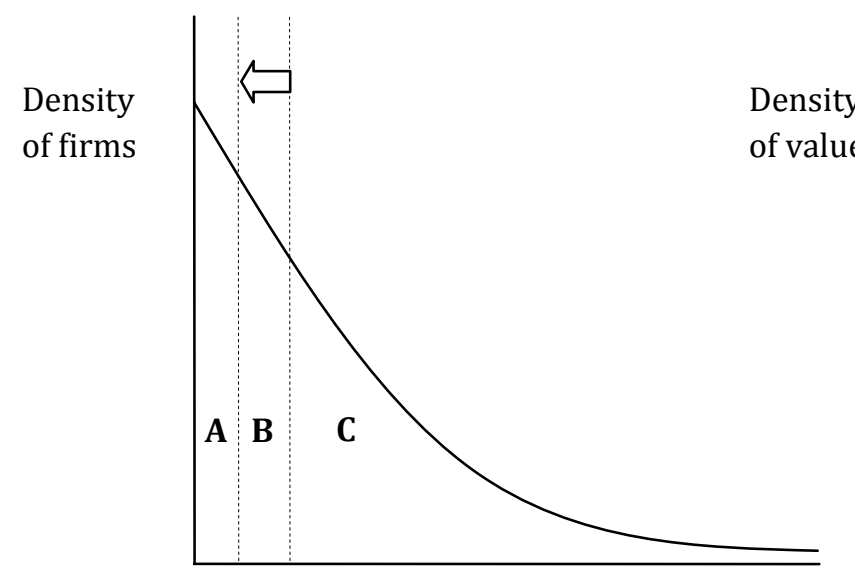

Firm value

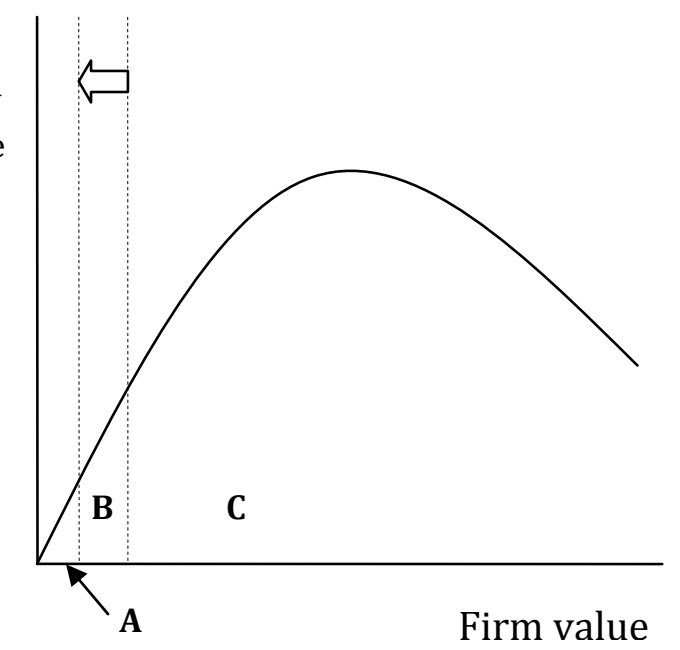

Figure 1b. Reducing the variable costs of doing business (e.g. port efficiency)

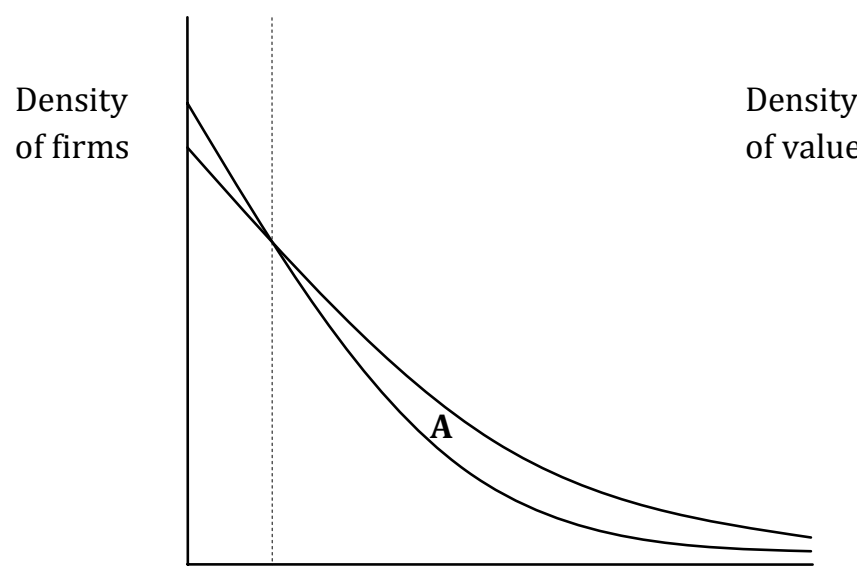

Firm value

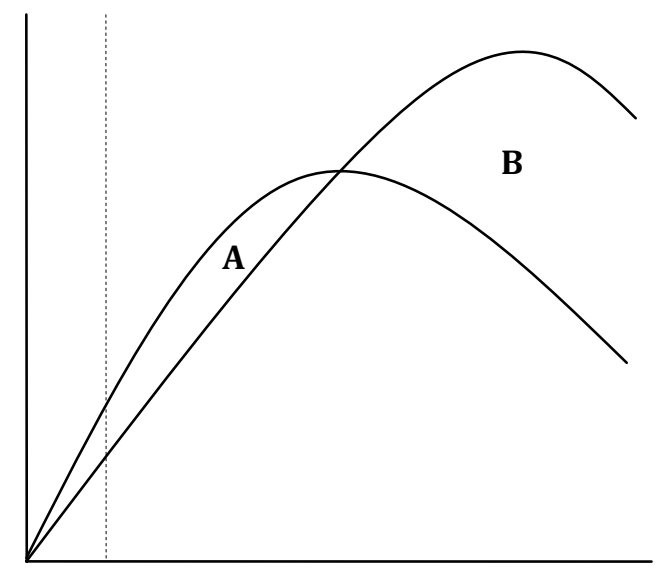

Firm value 
Economists have spent much time studying the costs and benefits of the wide range of regulations that affect industrial activity. The most active area of economics research on regulation over the last two decades has been the sectoral competition policies which define which firms can produce in which industries and under what rules. Such regulations tend to be sector-specific and to affect the largest and most concentrated industries, and are a major focus of the industrial organization literature; see Winston (1998). In contrast, this study's focus is on more broad-based regulatory and procedural burdens that apply to all firms at least in principle. This literature is much younger and less developed, in part because the requisite data has been unavailable until recently.

Several recent papers highlight patterns and trends in regulation across countries. Djankov et al (2002) finds that countries with high regulatory burdens facing firms tend to also be more corrupt and have larger unofficial economies, but do not have higher quality public or private goods. Djankov et al (2003) finds that procedural formalism in court cases regarding the non-payment of rent and the collection of bounced checks is associated with higher expected duration of judicial proceedings, more corruption, less consistency, and generally poorer outcomes. Djankov et al (2004) finds that countries which regulate labor more heavily also tend to have a larger unofficial economy, lower labor force participation, and higher unemployment, especially of the young. The datasets originated for these research projects have now been institutionalized as part of the Doing Business project at the World Bank, providing comparable measures of de jure business regulations across countries. Conway, Janod and Nicoletti (2005) show that entry barriers and restrictions on competition tend to be higher in countries that have higher barriers to foreign trade and investment, and also in countries with more cumbersome administrative procedures and policies that reduce the adaptability of labor markets. They also note that entry barriers and regulatory impediments to competition have declined in all OECD countries over 1998-2003. In general, the Doing Business database indicates a similar trend, with substantially more reductions than increases in the regulatory burden.

Research on the impacts of regulation on economic fundamentals picked up in the 1990s. On entry, Messina (2002) demonstrates theoretically that economy-wide entry barriers obstruct natural patterns of structural change by hindering the development of those sectors whose demand is income elastic, and provides evidence that the relative stringency of regulatory entry barriers across OECD countries helps explain differences in sectoral structure. Djankov et al (2006) use cross-sectional data from the World Bank's Doing Business project, finding a strong correlation 
between economic growth rates and indicators of business regulations: countries in the best quartile of regulations grow 2.3 percentage points faster than those in the worst quartile. Similarly, Desai, Gompers and Lerner (2003) find cross-country correlations between entry regulations and firm entry rates. Klapper, Laevan and Rajan (2004) use cross-sectional Doing Business data, finding that naturally high-entry industries have relatively lower entry rates and lower value-added growth rates (relative to naturally low-entry industries) in European countries that have more onerous bureaucratic entry regulations. In line with a view that emphasizes the distinction between de jure and de facto regulations, the result for entry rates holds primarily in less corrupt countries. They also study the impacts of other regulations, including country accounting standards and protection of intellectual property rights.

At a more micro level, Bertrand and Kramarz (2002) study the French retail trade industry, showing that stronger deterrence of entry by regional zoning boards increased retailer concentration and slowed employment growth. Jayaratne and Strahan (1998) exploit differential timing across states in the elimination of restrictions on US commercial bank expansion during the 1980s, finding improvements in bank performance in response. Kaplan, Piedra and Siera (2007) study a reform program in Mexico which opened one-stop-shops for business registration at different times in different states, finding a $4 \%$ increase in new registrations in response to the streamlined new procedures therein. Bruhn (2006) studies the same program, finding that new firms registering in response to the reforms were primarily started by wage workers opting to start their own business, rather than from the registration of existing informal firms. These latter two studies look at very similar regulatory issues as the present paper using a micro-level approach that is likely to be the most promising way forward for the literature.

On labor market regulations, a useful theoretical benchmark is Bentolila and Bertola (1990), who study firms' optimal hiring policies in a model with hiring and firing costs. They demonstrate that firing costs affect the firing policy of the firm much more dramatically than its hiring policy or average employment levels, and cite evidence of weak hiring responses to regulatory reductions in firing costs in the UK (1980-82), Germany (1985) and France (1986). However, they also note the large potential impacts of firing costs on productive efficiency if firms are imperfectly informed about worker quality and hence end up stuck with incompetent workers. The magnitude of the effects of hiring and firing costs varies strongly with the uncertainty facing firms going forward.

Empirically, Scarpetta et al (2002) use firm-level survey data from OECD countries to analyze firm entry and exit, finding that higher product market and labor regulations are negatively correlated 
with the entry of small and medium sized firms. Viviano (2006) exploits reforms to regional entry regulations in the Italian retail trade sector, finding that entry barriers have a negative impact on employment growth and on the efficiency of small firms. In an application to developing countries, Fallon and Lucas (1993) estimate dynamic labor demand equations for India and Zimbabwe, finding reductions in the demand for workers following enactment of more rigid labor laws. Among larger Indian plants, the drop in labor demand is estimated to be the largest where coverage of the legislation is more extensive, private ownership dominates, and there are fewer union members. Hasan, Mitra and Ramaswamy (2003) find that labor demand elasticities in Indian manufacturing are higher for Indian states with more flexible labor regulations. Besley and Burgess (2004) find that Indian states which imposed tighter labor regulations experienced reduced manufacturing output, employment, investment and productivity in formal sector manufacturing and increased output in informal manufacturing.

However, not all types of labor market rigidities are employment-reducing. In a survey of labor market regulations in Europe and North America, Nickell (1997) notes that long-term unemployment benefits, dense and un-coordinated union presence, high taxes on labor and high minimum wages for youth appear to have negative impacts on employment. However, he argues that there is little evidence from the OECD of negative employment effects from employment protection legislation and labor market standards, generous unemployment benefits accompanied by pressure to take jobs, and unionization offset by coordination in wage bargaining. MacIsaac and Rama (1997) show that the costs of mandated employee benefits in Ecuador are passed through in the form of reductions in wages for non-unionized workers, so effects on employment are negligible. Agnell (1999) summarizes arguments in favor of Europe's rigid labor markets, arguing that market imperfections may lead to inefficiently high wage differentials which can be rectified through regulation.

\section{Scope and contribution of the current study}

This study's focus is on more broad-based regulatory and procedural burdens that apply to all firms at least in principle. The datasets originated by Djankov et al $(2002,2003,2004)$, now institutionalized as part of the Doing Business project at the World Bank, provide four years of data on bureaucratic delays associated with starting or closing a business and on the rigidity of labor regulations. It also has three years of data for delays associated with registering commercial property. Labor regulations aside, these regulatory burdens are measured in terms of delays 
imposed on businesses, which are unlikely to enhance welfare or fix market failures. For instance, an environmental license for producers of hazardous chemicals may provide an important safety purpose, but long delays associated with such a license are unlikely to be socially beneficial. ${ }^{5}$ Practical data issues limit the scope of this study to a relatively small subset of the regulations and procedures covered by Doing Business; we discuss this in section 3.

As described above, dynamic models of firm behavior suggest that entry decisions, labor demand, capital accumulation and output can be negatively affected by binding business regulations which impose additional costs on firms when they enter, exit, expand, hire, fire, export, import, and so on. If these impacts are broad-based, one might expect reforms to move macroeconomic aggregates over time: for instance, eliminating labor laws which raise wages above market levels may attract investment, boost growth and bring unemployment rates down as firms become less reluctant to hire and expand. This paper looks for evidence of macroeconomic responses to regulatory reforms, specifically responses in investment rates (roughly, factor demand) and GDP growth conditional on investment (roughly, factor productivity). These series have high-coverage, decent-quality data available for the period 2003-07, allowing the use of Arellano-Bond estimators which explicitly address macroeconomic dynamics with at least some potential for statistical power. ${ }^{6}$ The empirical work aims to be parsimonious, controlling for important potential confounds but not intending to test all the correlates of macroeconomic outcomes.

This is not to imply that the aggregate level is the best place to look for potential impacts of regulatory reforms. As discussed below, some regulations may primarily affect small firms and hence be unlikely to influence macroeconomic aggregates. Some new research takes a more microeconomic perspective, and the present author views this as the best direction for future work.

${ }^{5}$ Djankov et al (2002) provide suggestive evidence that the regulation of entry as measured in these data is not a welfare-enhancing policy. In particular, they find that entry regulation levels are not correlated with any of the positive health and environmental outcomes they study, and are negatively associated with product market competition, product quality, governance and the size of the informal sector.

${ }^{6}$ A previous version of this paper considered unemployment rates and rates of new business entry. These variables are particularly of interest given the expected relationship between labor laws and unemployment and between business registration procedures and new business entry. However, the data coverage for these variables is quite poor, ruling out the use of dynamic panel data estimators (e.g. Arellano-Bond) and making the lack of results in the previous version unsurprising. 
The purpose of this paper is to address the question of what, if anything, can be said with confidence about the aggregate impacts of reform.

As mentioned above, clearly de jure regulations should only influence outcomes to the extent that they shape de facto regulations. For instance, Bertrand et al (2006) run a simple experiment on the process of obtaining a driver's license in India, finding that $71 \%$ of license getters avoided the mandated driving test and that extra-legal payments (averaging 1.5 times the official license fee) were common. However, in general we cannot observe the de facto regulatory burden, except possibly through direct surveys of firms. ${ }^{7}$ In this paper, as in the vast majority of research on regulations, we study de jure laws and regulations which we can observe and measure. We do investigate empirically whether these laws and regulations have more impact in better-governed countries where we would expect them to be implemented more consistently. The focus on de jure regulations is a shortcoming in some ways, but also in a sense is appropriate, as laws and regulations are the primary tools at the disposal of governments in the short- to medium-run. Implementation capacity and governance can be changed slowly at best. It is relevant to ask whether or not regulatory reforms have any impact given potential irregularities in enforcement, especially in the developing world. ${ }^{8}$

7 The World Bank's Enterprise Surveys are a useful first step in this direction.

8 It is also important to note that firms can and do avoid regulation and taxation by remaining informal, especially in developing countries. However, informality comes with large costs: informal firms must remain very small and maintain few fixed assets in order to avoid notice by law enforcement and to minimize the costs of being caught. In principle, if regulatory reforms - especially of entry barriers - result in formal sector investments and hires which would otherwise have been made in the informal sector and not recorded in the national statistics, then an estimate of the impact of reform on investment and employment to reform would be biased upwards. We argue that the quantitative impact of informality on the results is likely to be small. With respect to investment, informal sector firms hold little fixed capital, as they tend to be small, have limited access to finance, and are illegal and hence vulnerable to asset seizure. In the sample of Mexican micro-firms in Woodruff \& McKensie (2003), the 3,048 firms in construction, manufacturing, repair services, restaurants and hotels, and retail and wholesale trade had an average capital stock of $\$ 950$. Excluding retail and wholesale firms, whose capital stock mostly reflects inventories, the average capital stock is only $\$ 430$. The GDP of Mexico is \$1.07 trillion, so one percentage point of GDP corresponds to $\$ 10$ billion, equal to the fixed capital stock of more than 20 million informal firms. Any econometrically measurable impact of regulatory reform will be too large to explain through plausible shifts in firm registration rates. This exercise is similar in other poor countries: informal firms simply do not have enough fixed capital for increasing formalization to create measurable swings in investment rates over short periods of time. Similarly, the vast majority of informal sector firms have no employees, and those with employees have few, so the quantitative impact on measured unemployment rates of informal firms registering formally in response to reforms is likely to be small. In addition, employees of informal sector firms would not usually be counted among the unemployed in the first place, though measures of unemployment in developing countries in particular are questionably defined. 


\section{Data}

This section describes the data used in the empirical study, including business regulations, macroeconomic variables, indicators of the quality of government policies and institutions, and other controls.

\subsection{Business Regulations}

The data on regulatory burdens comes from the World Bank's Doing Business database, which provides data on many types of business regulations, including in the areas of entry, exit, licensing, hiring and firing, property registration, protection of investors, trade and customs, and contract enforcement. These regulations are often reformed from year to year, providing important variation that this study exploits in its empirical strategy. ${ }^{9}$

This database is explicitly focused on the de jure regulatory environment. Doing Business staff design a simple business case to ensure comparability across countries and over time, with assumptions about the legal form of the business, its size and the nature of its operations. They rely on the expert opinions of teams of lawyers, accountants and consultants in each country who study the relevant laws and regulations and arrive at estimates of how long procedures take and what the associated financial costs are. ${ }^{10}$ These teams have several rounds of interaction with the $D B$ team and provide the final data, which is cross-checked against the texts of the regulations and potentially also by government officials from the countries.

Practical considerations limit the scope of this study to a subset of the regulations and procedures covered by Doing Business. We restrict attention to indicators with at least three years of data between 2003 and 2007. We exclude indicators for which discrete reforms are difficult to identify. ${ }^{11}$

\footnotetext{
${ }^{9}$ While many regulations are tightly linked to legal frameworks, reforms do not always require changes in laws. For instance, El Salvador reduced the time to start a business from 115 days to 26 over three years by consolidating offices, adjusting internal procedures and re-training staff. (Doing Business 2007).

${ }^{10}$ The $D B$ methodology is discussed in detail at http://www.doingbusiness.org/.

${ }^{11}$ For instance, the cost of starting a business is measured as a share of GDP per capita, and the vast majority of the variation in the indicator comes from changes in GDP per capita. Attempts to reflate the data series to identify actual changes in the domestic currency cost of starting a business have not been successful.
} 
We focus here on indicators for time required to complete procedures rather than number of procedures, as both contain similar information in principle and produce similar results in practice. Finally, as illustrated below, some indicators do not exhibit enough variation over time to be useful in this study. As summarized in Table 1, the regulatory indicators which meet the criteria for inclusion are:

- Business registration: days to complete procedures to start a business

- Contract enforcement: days to complete procedures to enforce commercial contract

- Labor laws: overall index of the rigidity of labor regulations

- Property registration: days to complete procedures to register commercial property

- Import-export: days and cost to import or export containers

The first three series are available for 2003-07; property registration indicators are available for 2004-07; import-export indicators are available for 2005-07.

Table 2 provides the initial median values for the regulation indicators, and then categorizes countries as reformers, reversals or non-reformers on each indicator depending on whether they had a net reduction, increase or no change on that particular regulatory burden over the period 2003-07. To illustrate one of the points above, the table includes indices that do not have sufficient numbers of reforms to warrant statistical analysis. Note that most types of regulatory burdens fell on average over this period, with the exception of labor laws. Sixty-seven countries reformed their entry regulations, while ten made them more burdensome. Labor laws changed in 47 countries, equally in the directions of more and less rigid. As changes in the overall labor law index are accounted for primarily by reforms of hiring laws, the empirical work below focuses on the composite labor law rigidity index rather than breaking it into its sub-components. Finally, meaningful empirical analysis of the regulations and procedures affecting business closures is impractical given the small number of reforms thereof. This study focuses primarily on the number of days to start a business, the cost of registering property, and to a lesser extent the rigidity of employment laws index, because in these areas it at least has a chance of detecting meaningful reform impacts with statistical significance.

Similarly, the cost of registering commercial property is measured as a percentage of the property value, but the standardized property value is set at a fixed percentage of GDP.

15

Benjamin P. Eifert. 2009. "Do Regulatory Reforms Stimulate Investment and Growth? Evidince from the Doing Business Data, 2003-07." CGD Working Paper 159. Washington, D.C.: Center for Global Development. http://www.cgdev.org/content/publications/detail/1420894 
Table 3 looks at the timing of these reforms and reversals. Some countries reform a given regulation more than once over the period, so the sums of reforms across years can be greater than the entries in Table 2. Note that the timing of reforms within countries is uneven across years, with bursts of certain types of reform in certain years. The empirical work below uses the timing of reforms at the country level to identify the impacts of regulatory burdens.

Table 1. Selection of Regulatory Indicators

\begin{tabular}{|c|c|c|c|}
\hline Area & Indicator & $\begin{array}{l}\text { Included in } \\
\text { main } \\
\text { analysis? }\end{array}$ & Reason* \\
\hline \multirow{3}{*}{$\begin{array}{l}\text { Business } \\
\text { registration }\end{array}$} & Days to start a business & $\mathrm{Y}$ & - \\
\hline & Procedures to start a business & $\mathrm{N}$ & A \\
\hline & Cost to start a business (\% of GDP per capita) & $\mathrm{N}$ & $\mathrm{B}$ \\
\hline \multirow{3}{*}{$\begin{array}{l}\text { Property } \\
\text { registration }\end{array}$} & Days to register commercial property & Y & - \\
\hline & Procedures to register commercial property & $\mathrm{N}$ & A \\
\hline & $\begin{array}{l}\text { Cost to register commercial property ( } \% \text { of property } \\
\text { value) }\end{array}$ & $\mathrm{N}$ & B \\
\hline \multirow{3}{*}{$\begin{array}{c}\text { Contract } \\
\text { enforcement }\end{array}$} & Days to enforce a contract & $\mathrm{Y}$ & - \\
\hline & Procedures to enforce a contract & $\mathrm{N}$ & A \\
\hline & Cost to enforce a contract ( $\%$ of contract value) & $\mathrm{N}$ & $\mathrm{D}$ \\
\hline \multirow{4}{*}{ Labor laws } & Rigidity of hiring laws & $\mathrm{N}$ & $\mathrm{C}$ \\
\hline & Rigidity of firing laws & $\mathrm{N}$ & $\mathrm{C}$ \\
\hline & Rigidity of work hours laws & $\mathrm{N}$ & $\mathrm{C}$ \\
\hline & Overall rigidity of employment index & $\mathrm{Y}$ & - \\
\hline \multirow{4}{*}{$\begin{array}{c}\text { Port } \\
\text { procedures }\end{array}$} & Days to export a container & $\mathrm{Y}$ & - \\
\hline & Cost to export a container (\$US) & $\mathrm{Y}$ & - \\
\hline & Days to import a container & Y & - \\
\hline & Cost to import a container (\$US) & Y & - \\
\hline \multirow{2}{*}{$\begin{array}{c}\text { Business } \\
\text { exit }\end{array}$} & Years to close a business & $\mathrm{N}$ & $\mathrm{D}$ \\
\hline & Cost to close a business ( $\%$ of business value) & $\mathrm{N}$ & $\mathrm{D}$ \\
\hline
\end{tabular}

*A (parsimony), B(most time variation comes from movements in GDP), C (not enough independent variation over time), D (not enough variation over time). See text for more discussion. 
Table 2. Reformers, Reversals and Non-Reformers, 2003-07

\begin{tabular}{lccc}
\hline Indicator & Initial median & \# reformers & \# reversals \\
\hline Days to register a business & 40 & 67 & 10 \\
Procedures to register a business & 10 & 44 & 8 \\
Days to enforce a contract & 565 & 23 & 0 \\
Cost of enforcing a contract (\% of value) & 24.7 & 8 & 3 \\
Days to register commercial property & 47.5 & 25 & 6 \\
Procedures to register commercial property & 6 & 10 & 4 \\
Employment laws rigidity index & 34 & 21 & 34 \\
$\quad$ Hiring index & 33 & 3 & 30 \\
$\quad$ Firing index & 30 & 4 & 4 \\
$\quad$ Hours index & 40 & 17 & 3 \\
Cost to export a container $(\$)$ & 930 & 15 & 21 \\
Cost to import a container $(\$)$ & 1003 & 38 & 22 \\
Days to export a container & 20.5 & 38 & 5 \\
Days to import a container & 25 & 8 & 2 \\
Years to close a business & 2.8 & 5 & 1 \\
Cost to close a business $(\%$ of value) & 15 & 4 \\
\hline
\end{tabular}

Source: author's calculations from Doing Business dataset. 
Table 3. Reform Timing, 2003-07

\begin{tabular}{|c|c|c|c|c|c|c|c|c|}
\hline \multirow[t]{2}{*}{ Indicator } & \multicolumn{4}{|c|}{ Reforms } & \multicolumn{4}{|c|}{ Reversals } \\
\hline & $03-04$ & $04-05$ & $05-06$ & $06-07$ & $03-04$ & $04-05$ & $05-06$ & $06-07$ \\
\hline Days to start a business & 19 & 25 & 29 & 25 & 1 & 3 & 1 & 5 \\
\hline Procedures to start a business & 13 & 8 & 14 & 18 & 0 & 3 & 1 & 4 \\
\hline Days to enforce a contract & 8 & 9 & 5 & 1 & 0 & 0 & 0 & 0 \\
\hline Cost of enforcing a contract & 0 & 5 & 2 & 0 & 0 & 2 & 1 & 0 \\
\hline Days to register property & - & 3 & 12 & 10 & - & 2 & 3 & 1 \\
\hline Procedures to register property & - & 2 & 4 & 2 & - & 1 & 2 & 1 \\
\hline Employment index & 3 & 7 & 8 & 3 & 1 & 12 & 10 & 9 \\
\hline Hiring index & 2 & 7 & 5 & 2 & 0 & 11 & 8 & 8 \\
\hline Firing index & 1 & 0 & 3 & 0 & 1 & 1 & 1 & 1 \\
\hline Hours index & 0 & 0 & 3 & 1 & 0 & 0 & 1 & 2 \\
\hline Cost to export & - & - & 6 & 10 & - & - & 9 & 11 \\
\hline Cost to import & - & - & 4 & 10 & - & - & 11 & 10 \\
\hline Days to export & - & - & 19 & 20 & - & - & 2 & 3 \\
\hline Days to import & - & - & 19 & 22 & - & - & 0 & 2 \\
\hline Years to close a business & 1 & 1 & 5 & 1 & 0 & 1 & 0 & 0 \\
\hline Cost to close a business & 1 & 3 & 1 & 0 & 1 & 2 & 1 & 0 \\
\hline
\end{tabular}

Source: author's calculations from Doing Business dataset. 


\subsection{Macroeconomic Data and Control Variables}

As discussed above, this study primarily focuses on two dependent variables: per capita income growth and the aggregate investment rate, ${ }^{12}$ available from the World Bank's World Development Indicators. Data on investment rates are available for most countries over 2003-05, 2003-06 or 2003-07, for a total of 507 usable data points which also have at least some regulatory indicators.

By way of context, 2003-07 was a period of relatively strong economic performance across the world. For developed countries, 2003 marked recovery after the US slump of 2001-02. Among developing countries, some experienced sharp downturns - notably Argentina and Zimbabwe - but most have enjoyed growth rates in excess of those of the 1980s and 1990s. Lower- and middleincome countries saw investment rates rise by 3-4\% of GDP on average between 2002 and 2007; GDP growth rates also picked up by about $2 \%$ on average. Unemployment rates fell in middleincome countries, and rose slightly and then stabilized in high-income countries, though they appear to have risen in low-income countries. Between 2003 and 2005, rates of new business creation rose 0.5 percentage points in rich countries, 1 percentage point in middle-income countries and 1.5 percentage points in low-income countries. ${ }^{13}$

Some of these patterns could be over-interpreted. For instance, many countries have reformed their entry regulations, and investment rates are rising around the world, but this is not evidence that these two trends are causally related. The empirical analysis below looks for evidence that, conditional on business cycle position and other controls, countries which carry out reforms in particular years experience faster subsequent investment and employment growth.

The main empirical specifications below are relatively sparse, given the use of within-country variation, the limited quantity of data and the desire to maximize the number of usable observations. Because the main threat to econometric identification comes from unobserved economy-boosting public sector actions taken with similar timing to the observed regulatory reforms, our control variables are chosen to capture these.

12 Investment here is measured in domestic prices. Since only within-country variation is used in the empirical work, the use of market prices versus PPP in measuring investment is irrelevant.

13 Klapper et al (2007). 
Figure 2a. Average investment rates by income category, 2000-07 (unweighted)

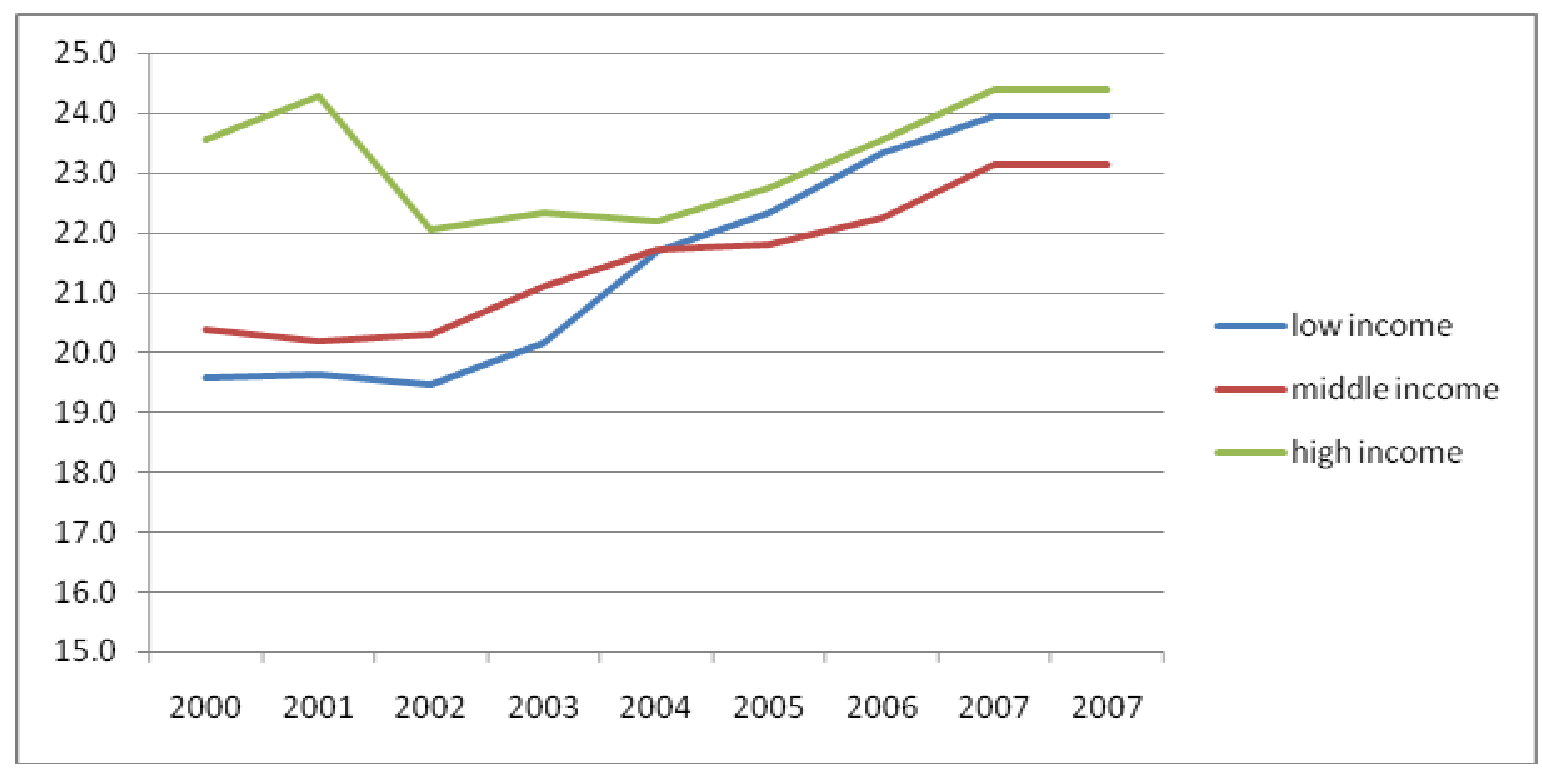

*Source: World Development Indicators. Definitions: low income $(<\$ 4,000$ per capita), middle income ( $\$ 4000-\$ 12000)$, high income $(>\$ 12,000)$. Some missing data points imputed. Averages are unweighted.

Figure 2b. Average GDP growth rates by income category, 2000-07

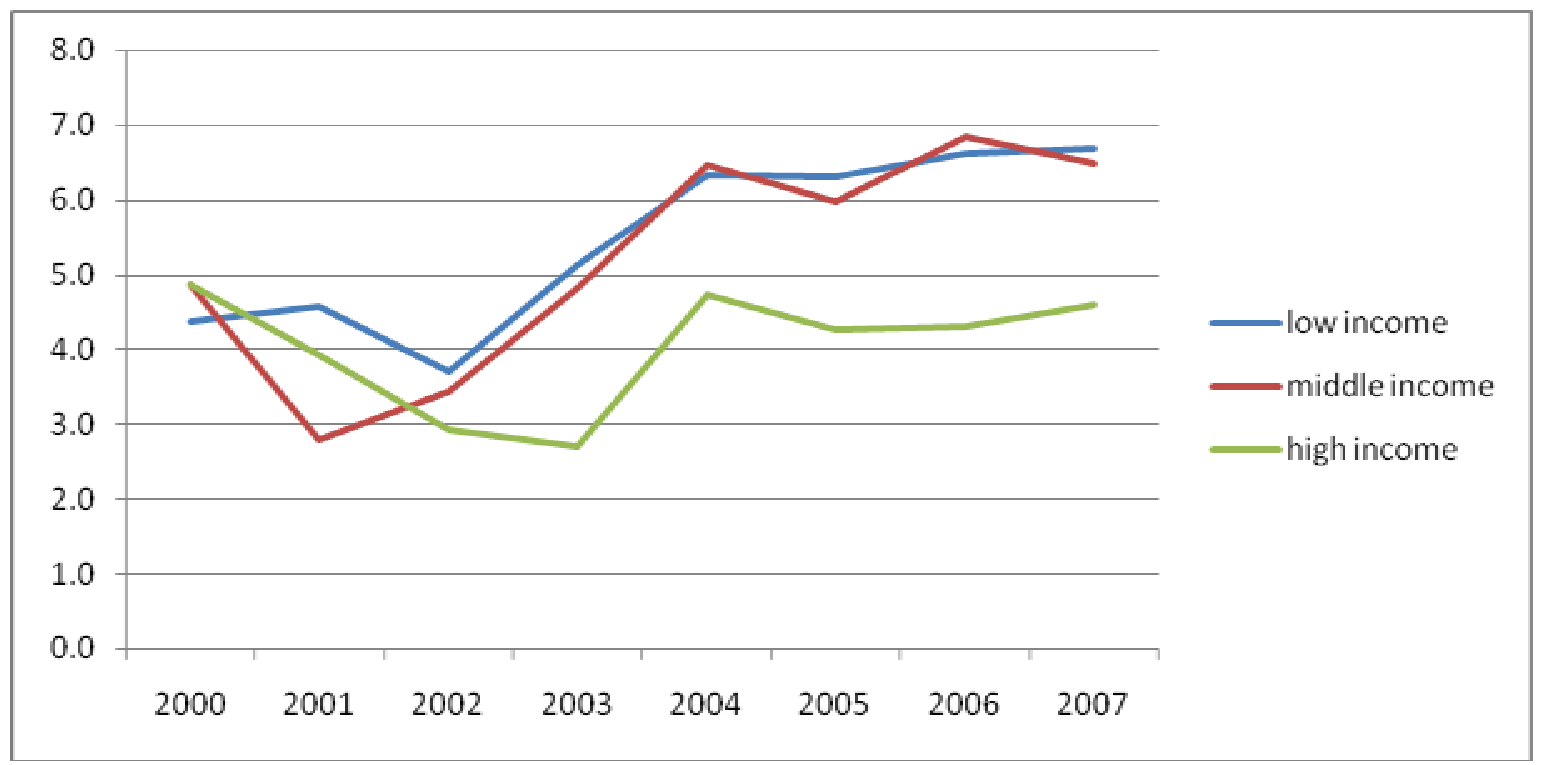

*Source: World Development Indicators. Definitions: low income $(<\$ 4,000$ per capita), middle income $(\$ 4000-\$ 12000)$, high income $(>\$ 12,000)$. Some missing data points imputed. Averages are unweighted.

Benjamin P. Eifert. 2009. "Do Regulatory Reforms Stimulate Investment and Growth? Evidince from the Doing Business Data, 2003-07." CGD Working Paper 159. Washington, D.C.: Center for Global Development. http://www.cgdev.org/content/publications/detail/1420894 
First, yearly averages of several measures of the quality of government policies and institutions from the International Country Risk Guide (ICRG) are included. ICRG's indices of economic risk, financial risk, and political risk are aggregated into a composite country risk index. These range from 0 (very poor environment) to 100 (very good environment), and are updated monthly by ICRG and sold to global investors, who use them to guide their risk assessments and investment decisions. Significant changes in the attitudes or policies of governments towards the private sector and changes in the risk environment facing investors should be picked up in these indices, helping to address potential biases associated with correlation between such changes and our observed regulatory reforms.

Second, the data on political freedoms and civil liberties generated by Freedom House are included to capture changes in countries' political environment which might have an effect on the confidence of the private sector. These measures range from 1 (free) to 7 (not free), and are averaged in the dataset to generate a composite measure of political openness.

Third, to capture the different implications of the large changes in oil prices over this period, every regression equation includes year fixed effects interacted with categorical variables for a country's dependence on oil exports. ${ }^{14}$

In a range of robustness checks, macroeconomic variables like inflation rates, real interest rates, and current account deficits were tested as controls. The limited coverage of these data and their weak correlations with reform timing led to a focus on sparser specifications.

We also test for different impacts of reform across subsets of countries. The most obvious test is whether reforms have a larger impact in wealthier or better-governed countries where regulations are more likely to be binding. We also check to see if reforms are more effective in more (or less) open economies. 15

14 The results are robust to several alternative definitions of oil dependence status. The one used below is whether a country is an oil importer, a minor oil exporter (fuel accounts for $<50 \%$ of exports) or a major oil exporter (fuel accounts for $>50 \%$ of exports).

${ }^{15}$ In an earlier version of the paper, we performed similar tests using indicators on financial system depth (measured by the share of credit allocated to the private sector) and infrastructure quality (measured by the share of electricity lost in transmission and the share of roads that are paved). However, the limited coverage of these variables make splitting the sample along these lines a statistically futile exercise. 


\section{Empirical Methods and Results}

We begin by studying patterns in reforms themselves. Do countries which enact regulatory reform over 2003-07 have systematically different characteristics than those which do not? Do countries tend to reform multiple indicators at once? These preliminary questions provide some insights into the types of challenges we face in identifying reform impacts. We then move on to the primary analysis of the macro-economic response to regulatory reform over 2003-07.

\subsection{Who Reforms?}

We begin by studying the characteristics of countries which pursue regulatory reform. Understanding which types of countries reform is an important question in of itself, with links to the political science and political economy literatures. One interesting question regards the relationship between initial regulatory burden and subsequent reform. On one hand, initially more burdensome regulatory environments may generate more political pressure for reform. On the other hand, such environments may be a reflection of political factors that generate pressure for heavy regulation, e.g. strong labor unions or cadres of rent-seeking regulators. Another interesting question is whether, conditional on initial level of regulation, countries with better policies and institutions are more likely to enact regulatory reforms, perhaps because their policymakers are more concerned with economic performance.

More importantly for our purposes here, patterns in which countries enact reforms are important for identification of the impact of reforms on economic outcomes. If we observe that countries with higher-quality policies and institutions are systematically more likely to undertake regulatory reform, we might worry that unobserved country characteristics are also different between reformers and non-reformers in a way that might bias our results.

As a starting point, we create a binary reform variable for each type of regulation we study, which takes the value of one if the country in question reduced the regulatory burden in that area over 2003-2007 and zero otherwise. We regress those binary variables on a set of country characteristics in the year 2003, including the initial level of the regulation in question, initial per capita income, levels and rates of change of economic, financial and political risk from International Country Risk Guide (ICRG), and levels and rates of change of political and civil rights from Freedom House. We estimate simple linear regressions of the form: 


$$
r_{j}=\mathbf{X}_{\mathbf{j}} \gamma+\xi_{j} \quad \xi_{j} \equiv r_{j}-\mathrm{P}\left(r_{j} \mid \mathbf{X}_{\mathbf{j}}\right)
$$

These regressions indicate what types of countries were more likely to enact regulatory reforms over the past half-decade.

A few discernable patterns come through in Table 4. The coefficients on initial regulatory levels are all positive and three of the eight are statistically significant, suggesting that countries with heavier regulatory burdens in 2003 were more likely to implement reforms over 2003-07. There is some weak evidence that more democratic countries (e.g. those with Freedom House scores closer to 1) are more likely to reform, with five out of eight coefficients negative and that on export costs also significant. The coefficients on the change in the ICRG country risk ratings are surprising: they come through negative in seven out of eight cases, and significant in the export costs equation. This suggests that if anything, reformers tend to be experiencing drops in broad-based ratings of the quality of their policies and institutions. The coefficients on the indicators for middle or high income country suggest that reformers are spread relatively evenly across the income distribution.

The most striking result in Table 4 is the relatively weak predictive power of the regressions. The lack of correlation between reform incidence and improvements in country ICRG ratings, except for the negative correlation indicated for reductions in the cost of exporting a container, is somewhat surprising. If anything, Table 3 points to a more idiosyncratic story about the decision to enact regulatory reforms, which will help below in attempts to identify the impacts of reform. A quick list of the most frequent reformers over this period is pretty disparate: Belarus, Czech Republic, Dominican Republic, Egypt, Georgia, Honduras, Hungary, India, Indonesia, Macedonia, Madagascar, Portugal, and Saudi Arabia. However, the power of the regressions is not overly strong, so these results should not be over-interpreted. 
Table 4. Who reforms?

\begin{tabular}{|c|c|c|c|c|c|c|c|c|}
\hline & (1) & (2) & (3) & (4) & (5) & (6) & (7) & (8) \\
\hline Variable & $\begin{array}{l}\text { Registe } \\
\text { r days }\end{array}$ & $\begin{array}{c}\text { Contrac } \\
\text { t days }\end{array}$ & $\begin{array}{l}\text { Propert } \\
\text { y days }\end{array}$ & $\begin{array}{l}\text { Labor } \\
\text { laws }\end{array}$ & $\begin{array}{l}\text { Export } \\
\text { cost }\end{array}$ & $\begin{array}{l}\text { Import } \\
\text { cost }\end{array}$ & $\begin{array}{l}\text { Expor } \\
\text { t days }\end{array}$ & $\begin{array}{l}\text { Import } \\
\text { days }\end{array}$ \\
\hline $\begin{array}{l}\text { Initial level of } \\
\text { regulation }\end{array}$ & $\begin{array}{c}0.212 \\
(0.051)^{*}\end{array}$ & $\begin{array}{c}0.156 \\
(0.114)\end{array}$ & $\begin{array}{c}0.070 \\
(0.043)\end{array}$ & $\begin{array}{c}0.053 \\
(0.073)\end{array}$ & $\begin{array}{c}0.151 \\
(0.095)\end{array}$ & $\begin{array}{c}0.190 \\
(0.087)\end{array}$ & $\begin{array}{c}0.154 \\
(0.126\end{array}$ & $\begin{array}{c}0.300 \\
(0.095)^{*}\end{array}$ \\
\hline $\begin{array}{l}\text { Freedom } \\
\text { house, level }\end{array}$ & $\begin{array}{c}0.010 \\
(0.026)\end{array}$ & $\begin{array}{l}-0.053 \\
(0.030)\end{array}$ & $\begin{array}{c}-0.033 \\
(0.047)\end{array}$ & $\begin{array}{c}-0.068 \\
(0.024)^{*}\end{array}$ & $\begin{array}{c}0.106 \\
(0.033)^{*}\end{array}$ & $\begin{array}{c}0.024 \\
(0.039)\end{array}$ & $\begin{array}{l}-0.003 \\
(0.041\end{array}$ & $\begin{array}{l}-0.021 \\
(0.037)\end{array}$ \\
\hline $\begin{array}{l}\text { Comprehensi } \\
\text { ve risk index, }\end{array}$ & $\begin{array}{c}0.007 \\
(0.008)\end{array}$ & $\begin{array}{l}-0.003 \\
(0.007)\end{array}$ & $\begin{array}{l}-0.005 \\
(0.009)\end{array}$ & $\begin{array}{l}-0.015 \\
(0.008)\end{array}$ & $\begin{array}{l}-0.004 \\
(0.007)\end{array}$ & $\begin{array}{c}0.004 \\
(0.008)\end{array}$ & $\begin{array}{l}-0.004 \\
(0.010\end{array}$ & $\begin{array}{c}0.002 \\
(0.010)\end{array}$ \\
\hline $\begin{array}{l}\text { Freedom } \\
\text { house, change }\end{array}$ & $\begin{array}{l}-0.052 \\
(0.090)\end{array}$ & $\begin{array}{l}-0.049 \\
(0.086)\end{array}$ & $\begin{array}{c}0.092 \\
(0.103)\end{array}$ & $\begin{array}{l}-0.167 \\
(0.087)\end{array}$ & $\begin{array}{c}0.002 \\
(0.103)\end{array}$ & $\begin{array}{l}-0.030 \\
(0.129)\end{array}$ & $\begin{array}{c}0.076 \\
(0.104\end{array}$ & $\begin{array}{c}0.023 \\
(0.101)\end{array}$ \\
\hline $\begin{array}{l}\text { Comp. risk } \\
\text { index, chg 03- }\end{array}$ & $\begin{array}{c}0.017 \\
(0.010)\end{array}$ & $\begin{array}{c}-0.001 \\
(0.013)\end{array}$ & $\begin{array}{c}-0.004 \\
(0.014)\end{array}$ & $\begin{array}{l}-0.014 \\
(0.013)\end{array}$ & $\begin{array}{c}-0.036 \\
(0.010)^{*}\end{array}$ & $\begin{array}{c}-0.014 \\
(0.015)\end{array}$ & $\begin{array}{l}-0.008 \\
(0.015\end{array}$ & $\begin{array}{l}-0.006 \\
(0.014)\end{array}$ \\
\hline $\begin{array}{l}\text { Middle } \\
\text { income }\end{array}$ & $\begin{array}{c}-0.136 \\
(0.086)\end{array}$ & $\begin{array}{c}0.041 \\
(0.129)\end{array}$ & $\begin{array}{l}-0.107 \\
(0.144)\end{array}$ & $\begin{array}{l}-0.066 \\
(0.125)\end{array}$ & $\begin{array}{c}0.118 \\
(0.129)\end{array}$ & $\begin{array}{c}-0.030 \\
(0.142)\end{array}$ & $\begin{array}{l}-0.047 \\
(0.141\end{array}$ & $\begin{array}{c}0.069 \\
(0.136)\end{array}$ \\
\hline $\begin{array}{l}\text { High income } \\
\text { country }\end{array}$ & $\begin{array}{c}-0.147 \\
(0.158)\end{array}$ & $\begin{array}{c}0.017 \\
(0.203)\end{array}$ & $\begin{array}{c}-0.064 \\
(0.250)\end{array}$ & $\begin{array}{c}0.030 \\
(0.176)\end{array}$ & $\begin{array}{c}0.083 \\
(0.200)\end{array}$ & $\begin{array}{c}-0.101 \\
(0.231)\end{array}$ & $\begin{array}{l}-0.216 \\
(0.236\end{array}$ & $\begin{array}{c}-0.171 \\
(0.227)\end{array}$ \\
\hline $\begin{array}{l}\text { Observations } \\
\text { R-squared }\end{array}$ & $\begin{array}{c}91 \\
0.24\end{array}$ & $\begin{array}{c}91 \\
0.07\end{array}$ & $\begin{array}{c}92 \\
0.07\end{array}$ & $\begin{array}{c}96 \\
0.10\end{array}$ & $\begin{array}{c}94 \\
0.27\end{array}$ & $\begin{array}{c}94 \\
0.07\end{array}$ & $\begin{array}{c}94 \\
0.16\end{array}$ & $\begin{array}{c}94 \\
0.23\end{array}$ \\
\hline
\end{tabular}




\subsection{Reform Packages}

Countries often implement packages of regulatory reforms, reworking overall port procedures to opening one-stop-shops for new firms offering streamlined registration and licensing. This section does two things. First, it explores whether countries which reform certain regulations over the period 2003-07 are more likely to reform others over this period as well. Second, it studies relationships among the timing of different types of reforms, investigating whether the introduction of one type of reform is likely to occur in the same year as the introduction of other types.

The important issues here are twofold. The more correlated is the incidence of various reforms, (i) the less statistical power we have to tease out the impacts of reform in our relatively small dataset, and (ii) the more we worry about unobserved economy-boosting measures bunched together with observed reforms, potentially creating a difficult omitted variables problem. To given an example of the latter, if governments which are streamlining business regulations out of a concern for the viability of small business also are investing more on average in small business loan programs, we would attribute the real impact of the unobserved loan programs to the business regulations.

First, we regress cross-sectional indicators for whether a country reformed a particular regulatory area over the sample period on indicators for reforms of other regulations. Table 5 documents the results for the full set of regulatory indicators, which are collectively available for 2005-07 only; the 2003-07 results for the subset of indicators available for the full period is very similar. In general, countries which reformed one piece of their business regulations were more likely to reform other aspects as well. Countries reforming business registration procedures were an estimated 16.9\% more likely to also reform their contract enforcement procedures. Reformers of contract enforcement procedures were $17.6 \%$ more likely to reform property registration procedures. Note the very strong relationship among export/import indicators: countries which reduce the time or cost to export a container also almost uniformly reduce the time or cost to import a container.

Second, we look at the within-country correlations among the set of regulatory indicators. The results in Table 6 are mixed. Reforms of import and export procedures clearly tend to occur in the same year. The only additional positive result is that countries reforming their business registration procedures in a given year are $13.3 \%$ more likely to also reform their labor laws. Table 6 definitely does not support a strong form of the reform package hypothesis, one in which reformist countries bundle changes together all or mostly in a single year's effort. This is at least suggestive that 
omitted variables problems generated by governments taking many unobserved economy-boosting measures simultaneously do not dominate the results below.

Table 5. Reformist countries?

\begin{tabular}{|c|c|c|c|c|c|c|c|c|}
\hline & (1) & (2) & (3) & (4) & (5) & (6) & (7) & (8) \\
\hline & $\begin{array}{l}\text { Registe } \\
\text { r days }\end{array}$ & $\begin{array}{l}\text { Contrac } \\
\text { t days }\end{array}$ & $\begin{array}{c}\text { Propert } \\
\text { y days }\end{array}$ & $\begin{array}{l}\text { Labor } \\
\text { laws }\end{array}$ & $\begin{array}{c}\text { Export } \\
\text { cost }\end{array}$ & $\begin{array}{c}\text { Import } \\
\text { cost }\end{array}$ & $\begin{array}{c}\text { Export } \\
\text { days }\end{array}$ & $\begin{array}{c}\text { Import } \\
\text { days }\end{array}$ \\
\hline RD & & $\begin{array}{c}0.127 \\
(0.073)\end{array}$ & $\begin{array}{c}0.159 \\
(0.087)^{*}\end{array}$ & $\begin{array}{c}-0.080 \\
(0.096)\end{array}$ & $\begin{array}{c}-0.070 \\
(0.066)\end{array}$ & $\begin{array}{c}0.055 \\
(0.064)\end{array}$ & $\begin{array}{c}-0.057 \\
(0.031)\end{array}$ & $\begin{array}{c}0.058 \\
(0.030)\end{array}$ \\
\hline CD & $\begin{array}{c}0.164 \\
(0.088)^{*}\end{array}$ & & $\begin{array}{c}0.215 \\
(0.112)\end{array}$ & $\begin{array}{c}0.198 \\
(0.110)\end{array}$ & $\begin{array}{c}0.004 \\
(0.037)\end{array}$ & $\begin{array}{c}0.008 \\
(0.038)\end{array}$ & $\begin{array}{c}-0.041 \\
(0.047)\end{array}$ & $\begin{array}{c}0.032 \\
(0.046)\end{array}$ \\
\hline PD & $\begin{array}{c}0.169 \\
(0.089)^{*}\end{array}$ & $\begin{array}{c}0.176 \\
(0.094)^{*}\end{array}$ & & $\begin{array}{c}0.093 \\
(0.103)\end{array}$ & $\begin{array}{c}0.050 \\
(0.060)\end{array}$ & $\begin{array}{c}-0.016 \\
(0.058)\end{array}$ & $\begin{array}{c}0.053 \\
(0.035)\end{array}$ & $\begin{array}{c}-0.017 \\
(0.026)\end{array}$ \\
\hline LL & $\begin{array}{c}-0.080 \\
(0.096)\end{array}$ & $\begin{array}{c}0.153 \\
(0.087)^{*}\end{array}$ & $\begin{array}{c}0.087 \\
(0.098)\end{array}$ & & $\begin{array}{c}-0.010 \\
(0.056)\end{array}$ & $\begin{array}{c}0.025 \\
(0.056)\end{array}$ & $\begin{array}{c}0.059 \\
(0.034)\end{array}$ & $\begin{array}{c}-0.057 \\
(0.033)\end{array}$ \\
\hline EC & $\begin{array}{c}-0.179 \\
(0.167)\end{array}$ & $\begin{array}{c}0.007 \\
(0.074)\end{array}$ & $\begin{array}{c}0.120 \\
(0.147)\end{array}$ & $\begin{array}{l}-0.025 \\
(0.144)\end{array}$ & & $\begin{array}{c}0.688 \\
(0.097)^{*} \\
*\end{array}$ & $\begin{array}{c}0.015 \\
(0.022)\end{array}$ & $\begin{array}{c}0.015 \\
(0.020)\end{array}$ \\
\hline IC & $\begin{array}{c}0.142 \\
(0.160)\end{array}$ & $\begin{array}{c}0.016 \\
(0.076)\end{array}$ & $\begin{array}{c}-0.038 \\
(0.141)\end{array}$ & $\begin{array}{c}0.065 \\
(0.146)\end{array}$ & $\begin{array}{c}0.697 \\
(0.094)^{*} \\
*\end{array}$ & & $\begin{array}{c}0.029 \\
(0.025)\end{array}$ & $\begin{array}{l}-0.005 \\
(0.018)\end{array}$ \\
\hline ED & $\begin{array}{c}-0.382 \\
(0.099)^{*} \\
*\end{array}$ & $\begin{array}{l}-0.211 \\
(0.223)\end{array}$ & $\begin{array}{c}0.336 \\
(0.161)^{*}\end{array}$ & $\begin{array}{c}0.397 \\
(0.139)^{*} \\
*\end{array}$ & $\begin{array}{c}0.040 \\
(0.059)\end{array}$ & $\begin{array}{c}0.076 \\
(0.062)\end{array}$ & & $\begin{array}{c}0.941 \\
(0.031)^{*} \\
*\end{array}$ \\
\hline ID & $\begin{array}{c}0.374 \\
(0.083)^{*} \\
*\end{array}$ & $\begin{array}{c}0.159 \\
(0.221)\end{array}$ & $\begin{array}{c}-0.101 \\
(0.153)\end{array}$ & $\begin{array}{c}-0.368 \\
(0.124)^{*} \\
*\end{array}$ & $\begin{array}{c}0.037 \\
(0.048)\end{array}$ & $\begin{array}{c}-0.013 \\
(0.045)\end{array}$ & $\begin{array}{c}0.913 \\
(0.043)^{*} \\
*\end{array}$ & \\
\hline $\begin{array}{l}\text { Years } \\
\text { Countrie } \\
\mathbf{S} \\
\mathbf{R}^{2}\end{array}$ & $\begin{array}{c}2005-07 \\
121 \\
0.08\end{array}$ & $\begin{array}{c}2005-07 \\
121 \\
0.13\end{array}$ & $\begin{array}{c}2005-07 \\
121 \\
0.18\end{array}$ & $\begin{array}{c}2005-07 \\
121 \\
0.09\end{array}$ & $\begin{array}{c}2005-07 \\
121 \\
0.56\end{array}$ & $\begin{array}{c}2005-07 \\
121 \\
0.55\end{array}$ & $\begin{array}{c}2005-07 \\
121 \\
0.87\end{array}$ & $\begin{array}{c}2005-07 \\
121 \\
0.86\end{array}$ \\
\hline
\end{tabular}


Table 6. Reform packages?

\begin{tabular}{|c|c|c|c|c|c|c|c|c|}
\hline & (1) & (2) & (3) & (4) & (5) & (6) & (7) & (8) \\
\hline & $\begin{array}{c}\text { Registe } \\
\text { r days }\end{array}$ & $\begin{array}{c}\text { Contrac } \\
\text { t days }\end{array}$ & $\begin{array}{c}\text { Propert } \\
\text { y days }\end{array}$ & $\begin{array}{c}\text { Labor } \\
\text { laws }\end{array}$ & $\begin{array}{c}\text { Export } \\
\text { cost }\end{array}$ & $\begin{array}{c}\text { Import } \\
\text { cost }\end{array}$ & $\begin{array}{c}\text { Export } \\
\text { days }\end{array}$ & $\begin{array}{c}\text { Import } \\
\text { days }\end{array}$ \\
\hline SD & & $\begin{array}{c}0.038 \\
(0.031)\end{array}$ & $\begin{array}{c}0.072 \\
(0.055)\end{array}$ & $\begin{array}{c}0.080 \\
(0.046) \\
*\end{array}$ & $\begin{array}{c}0.043 \\
(0.033)\end{array}$ & $\begin{array}{c}-0.049 \\
(0.030)\end{array}$ & $\begin{array}{c}0.003 \\
(0.031)\end{array}$ & $\begin{array}{c}-0.023 \\
(0.034)\end{array}$ \\
\hline CD & $\begin{array}{c}0.177 \\
(0.137)\end{array}$ & & $\begin{array}{c}-0.038 \\
(0.153)\end{array}$ & $\begin{array}{c}0.088 \\
(0.162)\end{array}$ & $\begin{array}{c}0.011 \\
(0.027)\end{array}$ & $\begin{array}{c}0.039 \\
(0.033)\end{array}$ & $\begin{array}{c}-0.034 \\
(0.073)\end{array}$ & $\begin{array}{c}-0.012 \\
(0.069)\end{array}$ \\
\hline PD & $\begin{array}{c}0.108 \\
(0.082)\end{array}$ & $\begin{array}{c}-0.012 \\
(0.049)\end{array}$ & & $\begin{array}{c}0.021 \\
(0.073)\end{array}$ & $\begin{array}{c}0.042 \\
(0.032)\end{array}$ & $\begin{array}{c}-0.051 \\
(0.030)\end{array}$ & $\begin{array}{c}-0.002 \\
(0.043)\end{array}$ & $\begin{array}{c}0.051 \\
(0.047)\end{array}$ \\
\hline EMP & $\begin{array}{c}0.133 \\
(0.075) \\
*\end{array}$ & $\begin{array}{c}0.031 \\
(0.058)\end{array}$ & $\begin{array}{c}0.024 \\
(0.082)\end{array}$ & & $\begin{array}{c}-0.020 \\
(0.029)\end{array}$ & $\begin{array}{c}-0.006 \\
(0.030)\end{array}$ & $\begin{array}{l}-0.020 \\
(0.056)\end{array}$ & $\begin{array}{c}0.048 \\
(0.057)\end{array}$ \\
\hline EC & $\begin{array}{c}0.186 \\
(0.144)\end{array}$ & $\begin{array}{c}0.010 \\
(0.025)\end{array}$ & $\begin{array}{c}0.124 \\
(0.095)\end{array}$ & $\begin{array}{c}-0.054 \\
(0.077)\end{array}$ & & $\begin{array}{c}0.625 \\
(0.093)^{*} \\
*\end{array}$ & $\begin{array}{c}0.024 \\
(0.085)\end{array}$ & $\begin{array}{c}0.099 \\
(0.090)\end{array}$ \\
\hline IC & $\begin{array}{c}-0.238 \\
(0.145) \\
*\end{array}$ & $\begin{array}{c}0.040 \\
(0.035)\end{array}$ & $\begin{array}{l}-0.165 \\
(0.099)\end{array}$ & $\begin{array}{l}-0.019 \\
(0.085)\end{array}$ & $\begin{array}{c}0.690 \\
(0.096)^{*} \\
*\end{array}$ & & $\begin{array}{c}0.201 \\
(0.085)^{*}\end{array}$ & $\begin{array}{l}-0.118 \\
(0.093)\end{array}$ \\
\hline ED & $\begin{array}{c}0.012 \\
(0.104)\end{array}$ & $\begin{array}{c}-0.025 \\
(0.053)\end{array}$ & $\begin{array}{c}-0.005 \\
(0.097)\end{array}$ & $\begin{array}{c}-0.040 \\
(0.113)\end{array}$ & $\begin{array}{c}0.019 \\
(0.066)\end{array}$ & $\begin{array}{c}0.141 \\
(0.063)^{*}\end{array}$ & & $\begin{array}{c}0.836 \\
(0.048)^{*} \\
*\end{array}$ \\
\hline ID & $\begin{array}{c}-0.075 \\
(0.107)\end{array}$ & $\begin{array}{c}-0.008 \\
(0.047)\end{array}$ & $\begin{array}{c}0.107 \\
(0.099)\end{array}$ & $\begin{array}{c}0.091 \\
(0.104)\end{array}$ & $\begin{array}{c}0.072 \\
(0.064)\end{array}$ & $\begin{array}{c}-0.078 \\
(0.060)\end{array}$ & $\begin{array}{c}0.789 \\
(0.051)^{*} \\
*\end{array}$ & \\
\hline $\begin{array}{l}\text { Observatio } \\
\text { ns }\end{array}$ & 363 & 363 & 363 & 363 & 363 & 363 & 363 & 363 \\
\hline Countries & 128 & 128 & 128 & 128 & 128 & 128 & 128 & 128 \\
\hline R-squared & 0.05 & 0.03 & 0.04 & 0.03 & 0.51 & 0.51 & 0.71 & 0.70 \\
\hline
\end{tabular}




\subsection{Estimating Economic Responses to Regulatory Reform}

This section turns to the main question of interest: did the reforms observed over 2003-07 elicit meaningful macroeconomic responses, measured by either increased factor demand (investment rates) or factor productivity (GDP growth conditional on investment rates)?

\section{Methodology}

The research on the impacts of regulation in section 3 primarily uses three methodologies. The first relies on pure cross-sectional correlations between regulatory indicators and measures of economic performance, (Djankov et al 2006; Desai, Gompers \& Lerner 2003; Nickell 1997; Scarpetta et al 2002). These models are of the form:

$$
y_{i}=x_{i}^{\prime} \beta+\varepsilon_{i}
$$

Where $i$ indexes countries or firms, $y_{i}$ is some measure of economic performance like the average growth rate over some extended period of time, and $x_{i}$ contains measures of regulations and control variables. The identifying assumption is $E\left[\varepsilon_{i} \mid x_{i}\right]=0$, e.g. that there are no unobserved country characteristics correlated with regulatory levels which also have a causal impact on economic performance. These studies provide interesting patterns, especially those using firm-level data, but cannot provide much support for causal inference because of omitted variables and simultaneity problems. For instance, countries with more stringent firing restrictions may have higher unemployment rates, but high unemployment rates may give rise to political pressure for employment protection. Similarly, countries with higher regulatory entry barriers may also have more state intervention in price-setting, which is harder to observe and hence probably omitted. All such stories cause $E\left[\varepsilon_{i} \mid x_{i}\right] \neq 0$.

The second set of methods follows Rajan and Zingales (1998) in using cross-sectional difference-indifference methods (Hasan, Mitra and Ramaswamy 2003; Klapper, Laevan and Rajan 2004). The idea is to compare differences in outcomes between sectors or industries which should be differentially affected by the regulations in question. That is:

$$
y_{i j}=\left(x_{i} s_{j}\right)^{\prime} \gamma+c_{i}+v_{j}+\varepsilon_{i j}
$$


Where $i$ indexes countries, $j$ indexes sub-national units (e.g. sectors), and $s_{j}$ is some stratification along which the impact of regulations should vary. The identifying assumption is that $E\left[\varepsilon_{i} \mid s_{j}, c_{i}, v_{j}\right]=0$ : that is, the error may be correlated with the level of regulations but not with the stratum by which the impact of regulations varies.

This basic method is a substantial improvement over pure cross-sectional correlations, as it is robust to unobserved country heterogeneity in the levels of the dependent variables that might be correlated with the independent variables of interest. However, these methods are still limited by their inherently cross-sectional nature. For instance, sectors which are "naturally high-entry" and hence should be affected more by entry barriers are generally characterized by more basic technologies and lower minimum efficient scale; entry rates in such sectors might also be differentially affected by other types of policies or regulations which are correlated with entry barriers, like small business loan programs. Also, these methods do not allow the estimation of absolute impacts of regulations, only the extra impact of regulations in more sensitive sectors.

The third set of methods uses panel data with fixed-effects or difference-in-difference estimators (Bertrand and Kramarz 2002, Jayaratne and Strahan 1998). The idea here is to look at differential changes in regulations across countries, regions or industries and to link those to corresponding changes in economic outcomes. That is:

$$
y_{i t}=x_{i t}^{\prime} \beta+c_{i}+v_{t}+\varepsilon_{i t}
$$

The identifying assumption is $E\left[\varepsilon_{i t} \mid x_{i t}, c_{i}, v_{t}\right]=0$, e.g. the error term must be uncorrelated with the regulatory indicators of interest once we condition on the time-invariant country effects and country-invariant time effects.

The focus on the timing of reforms within countries over a several year period, rather than on the levels of regulation or even the simple reform/no-reform comparison, brings several advantages. It allows us to clean out unobserved time-constant heterogeneity across units of observation: If, for instance, countries with more stringent regulations also make more direct interventions in markets through state-owned enterprises, our fixed-effects estimator will be valid as long as those patterns do not change together year-on-year. With enough subsequent observations on each country, a panel study at the country level can even control for idiosyncratic country-specific trends in the 
dependent variable of interest, so any unobserved variables that are driving changes in investment rates or unemployment rates and which are roughly constant over 2003-06 cannot bias our results.

An important remaining concern about equation (4) is the dynamics of macroeconomic variables. In particular, output, unemployment and investment rates follow persistent, cyclical processes with substantial autocorrelation. If the timing of reforms is correlated with the business cycle then equation (4) will deliver biased coefficient estimates. For example, if reforms tend to be motivated by and enacted in economic downturns, then subsequent improvements in the state of the economy should be expected whether or not the reforms had any impact, and coefficients on reforms in (4) will be upward-biased. Similarly, if reforms tend to be easier to enact in times of prosperity, then macroeconomic indicators will tend to turn down with the business cycle, biasing downward the coefficients on reforms.

Macroeconomic dynamics imply that a more appropriate specification is:

$$
\Leftrightarrow \Delta y_{i t}=\alpha_{1} \Delta y_{i t-1}+\ldots+\alpha_{p} \Delta y_{i t-p}+\Delta x_{i t}^{\prime} \beta+\Delta v_{t}+\Delta \varepsilon_{i t}
$$

This model relates changes in $y_{i t}$ to changes in current and possibly lagged values of regulatory indicators and control variables $x_{i t}$, conditional on the dynamics of the macroeconomic process $y_{i t}$. Unlike (4), this equation cannot be directly estimated using fixed effects or first-differences, because of the presence of lagged dependent variables. In particular, the error term $\Delta \varepsilon_{i t}$ is mechanically correlated with the left-hand-side variable $\Delta y_{i t-1}$. The standard solution is to use the Arellano-Bond dynamic panel estimator, which uses lagged levels of $y_{i t}$ as instruments for the lagged $\Delta y_{i t}$ terms. The orthogonality conditions required for consistency are of the form $E\left(\Delta \varepsilon_{i t} \mid \Delta x_{i t}, \Delta v_{t}, y_{i t-1} \ldots y_{i t-r}\right)=0$. That is, conditional on control variables and the state of the macroeconomic process $y_{i t}$, the timing of the regulatory reforms we are interested in cannot be correlated with time-varying unobservables that drive $y_{i t}$.

The main challenge in identifying economic responses to particular government actions, including regulatory reforms, is that we are unlikely to be able to observe and account for all the relevant actions. If some governments are more likely than others to take several economy-boosting measures over a several year period, but those measures tend to be randomly distributed over the period, then a fixed-effects regression exploiting only variance within countries over time can identify reform impacts. However, if governments tend to take multiple actions simultaneously 
then one faces an omitted variables problem. For example, if governments which streamline business regulations out of a concern for the viability of small business also simultaneously invest more in small business loan programs, we would attribute the impact of the unobserved loan programs to the business regulations. We include broader measures of the quality of policies and institutions, such as ICRG's country risk indices, in hopes of addressing this as best as possible.

Finally, the drawbacks of within estimators in terms of statistical power have already been mentioned, but it is worth re-emphasizing this point here. We trim outliers in hopes of keeping standard errors down as much as possible, removing observations in the top and bottom $1 \%$ of changes in investment rates and growth rates. The hope here, analyzed in detail below, is that there is enough statistical information in within-country variation to make it worth using methods which are robust to some of the major pathologies of empirical research.

One more note on the timing of reforms is in order. The $D B$ indicators reflect regulatory conditions at the beginning of the year, so a reform which occurred midway through 2003 is recorded as a reform over 2003-04, but could plausibly impact economic outcomes in 2003. Tests find no evidence of a within-country correlation between current regulatory indicators and lagged economic outcomes conditional on current economic outcomes.

\section{Basic Results}

Table 7 presents the basic results. Columns 1 and 4 include only the three indicators available for the full period 2003-07: days to register a business, days to enforce a contract, and labor law rigidity. Columns 3 and 6 include lags of these variables as well. Columns 2 and 4 pull in the full set of regulatory indicators, including days to register property, days to export a container and cost to export a container, and hence cover only the period 2005-07.16

The results for investment rates in columns 1-3 are completely negative. All the coefficients on days to start a business and two of the three coefficients on labor regulations go in the right direction, but are all insignificant. The indicators for export procedures and property registration procedures have inconsistent, insignificant coefficients. Including lags and/or nonlinear terms, dropping

\footnotetext{
${ }^{16}$ Import procedures are left out given their very high within-country correlation with export procedures.
} 
control variables, and other similar exercises turned up little. The positive, borderline-significant coefficients on lagged investment rates indicate some degree of persistence in investment.

The standard errors on reform indicators are moderately large, underscoring the concern about statistical power. From column 1, the estimated effect on investment rates of a one-standarddeviation (10-day) reduction in business registration delays has a confidence interval of [-0.04, +0.26 ]. This confidence interval widens substantially in column 2, which uses three years of data instead of five. Basically, one can reject the hypothesis of very large positive impacts - in this case, an investment response of more than a quarter of a percent of GDP - but cannot rule out more modest responses with precision. We tried several things to increase power by reducing multicollinearity, including estimating only one reform coefficient at a time and dropping the control variables, but the lack of positive results was consistent.

Columns 4-6 present a slightly more positive picture. The coefficients on days to enforce a contract are all negative and two are significant. The median reform reduces the number of days to enforce a contract by 38; taking the coefficient of -0.006 from Table 7 , a reform of this magnitude is associated with a $0.23 \%$ boost to GDP growth, with a confidence interval of $[+0.08,+0.38]$. However, the coefficients on labor regulations are still insignificant though in the right direction, those on days to start a business are insignificant and in the wrong direction, and there are no results for property registration or import/export procedures. The comments above about lags, nonlinearities and standard errors apply.

Figure 3 illustrates these findings visually. The graphs are semi-parametric estimates of the relationship between reforms and investment or growth rates, implemented by first partialing out fixed effects and control variables from the dependent and independent variables and then fitting fractional polynomial regressions using the residuals. There is some suggestive slope in the righthand panels for contract enforcement and employment rigidity, corresponding to a weak relationship between reforms and increases in GDP growth rates. However, the confidence intervals (shaded in grey) are large and expand rapidly for big reforms. Overall, the existing data cannot support strong assertions one way or the other about the aggregate impacts of the individual regulations and procedures studied here. 


\section{Heterogeneous impacts?}

There are reasons to believe that the impacts of these reforms may vary with country characteristics. We investigate this possibility by splitting the sample in several intuitive ways and re-estimating the multivariate investment regressions in the relevant subsets of countries. Table 10 contains the estimates for the three indicators which are available for five years; the others have too little data to realistically engage in sample-splitting exercises.

The most obvious possibility is that the implementation and enforcement of regulations, and hence their effects, depends on the quality of the bureaucracy responsible for those regulations. We reestimate the regressions for countries (i) above the median per capita income level in the sample, and (ii) above the median ICRG composite rating in the sample. We also split the sample at the median level of trade openness, measured using imports plus exports as a share of GDP. The idea here is that economies which are more open to international competition might be more sensitive to high costs of regulation. ${ }^{17}$ Importantly, each split on a particular country characteristic is done after partialing out the other two indicators. So for example, the interpretation of the difference between a particular reform coefficient for richer countries versus poorer countries has only to do with differences across per capita income and not differences across governance or trade openness.

Table 8 displays the results for the investment equation, which are striking. Business registration reforms are associated with increases in investment rates in countries which have relatively better policies (ICRG ratings), and in countries which are relatively poorer. In both sets of countries the impact on investment rates of a median-sized reform of -10 days to registration delays is consistently estimated around +0.30 percentage points. The estimated coefficients are similar across countries which are more or less integrated into world markets; the one on less open countries is borderline significant. The results for contract enforcement and labor laws are less interesting, with insignificant differences between different categories of countries.

Table 9 shows the results for GDP growth conditional on investment rates. The median reform of business registration procedures, reducing registration delays by 10 days, is associated with a +0.36 percent boost to growth in relatively poor countries, with a confidence interval of $[+0.10$,

\footnotetext{
${ }^{17}$ A previous version of this paper also split the sample by infrastructure quality and financial sector depth.
} However, the weak coverage of this data makes splitting the sample an exercise in very low statistical power. 
$+0.62]$. Countries with better policies also show an estimated negative impact of registration delays, while the coefficient in the worse-policies column is essentially zero, but the difference is not significant. Reductions in contract enforcement delays also have apparent positive impacts in poorer countries and those with better policies, with the median reform (-38 days) associated with a 0.3-0.4 percent boost to GDP growth rates. As with investment rates above, the estimated coefficients are similar across countries which are more or less integrated into world markets, but only the one on less open countries is at least borderline significant. Again, the results for labor laws are consistently in the wrong direction, though insignificant.

These findings are remarkably consistent given the small sample sizes, and to some extent line up with intuition. Holding governance constant, poorer countries potentially have more to lose from large business startup costs or legal bottlenecks, as a large share of their potential entrepreneurs have very little capital and lack the education to navigate complex bureaucratic or legal procedures. Holding income levels constant, better-governed countries also potentially have more to lose from burdensome regulations and procedures because their bureaucracies actually enforce those procedures. Poor countries that are better-managed than average for their income level - like China and India, containing something like half the world's poor, plus countries like Ghana and Uganda in Africa - may have real opportunities to gain from reform.

However, as discussed earlier, it seems unintuitive that labor regulations - which increase the variable costs of large, high-productivity firms - should have little or no estimated impacts on macroeconomic aggregates, while business registration procedures which only screen out lowproductivity firms have a significant impact. The source of this discrepancy remains a source of concern. The issue remains that the coefficients may be picking up some broader impacts of other economy-boosting measures taken by governments at the same time as the regulatory reforms, though the fact that reform incidence is uncorrelated with improvements in the quality of the broader policy environment over 2003-07 (as measured by ICRG scores) is somewhat comforting. ${ }^{18}$

\footnotetext{
${ }^{18}$ It is worth noting that in a previous version of the paper, the one positive finding here was a significant positive correlation between unemployment and the rigidity of labor laws in wealthier countries. The coefficient was very (perhaps implausibly) large: moving from the $75^{\text {th }}$ to the $25^{\text {th }}$ percentile of rigidity, the difference between Germany and Ireland, was associated with a huge 5.8 percentage point reduction in unemployment.
} 


\section{Aggregation}

The methods above attempt to identify the impacts of different types of reforms. Multicollinearity among regulatory indicators within countries over time is not too strong, so this is a reasonable thing to do, and the results are suggestive. However, one might also be interested in whether countries which reform one or more area of their regulations and procedures in a particular year outperform other countries in that year and in the subsequent year.

We do not map the levels of regulatory burden into an index, which would require many arbitrary choices about how to aggregate. Since there are relatively few country-year observations with two or more reform areas, especially in the 2003-07 panel with only three regulatory indicators, we simply create an indicator variable $r_{i t}$ for whether or not country $i$ carried out one or more reforms in year $t$. The first definition of "reform" we use is any year-on-year reduction in the regulatory burden for a particular indicator. The alternative, stronger definition is a year-on-year reduction in a regulatory indicator of at least $1 / 2$ times the standard deviation of within-country changes in that indicator. The results are quite similar for both definitions, so only those from the first are displayed below.

We first take the investment and GDP growth data and partial out the standard set of covariates and year and country fixed effects. We then compare the means of these macroeconomic indicators across the reform/no-reform categories, both for current reforms (top pane of Table 10) and lagged reforms (bottom pane). We do so within three sets of countries: the whole sample, countries below the median per capita income level in the sample, and countries below the median ICRG rating in the sample. ${ }^{19}$

Table 10 underpins the findings from Tables 8-9. In the sample as a whole, countries do no better in the years in which they reform or in the subsequent years. However, relatively poor countries and those with relatively good policies both grow significantly faster conditional on their investment rates in reform years, about 0.4 and 0.2 percentage points faster, respectively. Similarly, their

\footnotetext{
${ }^{19}$ As before, this is done conditionally, such that the sample-split along the lines of income is orthogonal to ICRG rating, and vice versa. While it might seem like a good idea to do a four-way split of the sample along both income and governance lines, the number of observations in each cell would start to get very small, so this is not done here.
} 
investment rates accelerate significantly in the year after they reform, by about 0.6 percentage points.

These results suggest that relatively well-managed poor countries stand to gain from a broad push for streamlining regulations and procedures affecting businesses. The correlations above could in principle be partly spurious, if governments which enact regulatory reforms simultaneously push through other economy-boosting reform measures that we do not observe. This would be an omitted variables problem that would be challenging to solve, and would render strong claims about the impacts of individual reforms suspect. However, it would still be consistent with general optimism about the prospects for governments making broad sets of policy reforms. 
Table 7. Do Economies Respond to Regulatory Reform?

\begin{tabular}{|c|c|c|c|c|c|c|}
\hline & \multicolumn{3}{|c|}{ Investment (\% of GDP) } & \multicolumn{3}{|c|}{ GDP growth rate (\%) } \\
\hline D. Investment & & & & $\begin{array}{c}0.052 \\
(0.108)\end{array}$ & $\begin{array}{c}0.163 \\
(0.098)\end{array}$ & $\begin{array}{c}0.193 \\
(0.100)^{*}\end{array}$ \\
\hline LD. Investment & $\begin{array}{c}0.339 \\
(0.288)\end{array}$ & $\begin{array}{c}0.255 \\
(0.294)\end{array}$ & $\begin{array}{c}0.467 \\
(0.255)^{*}\end{array}$ & & & $\begin{array}{c}-0.009 \\
(0.086)\end{array}$ \\
\hline L2D. Investment & $\begin{array}{c}0.046 \\
(0.070)\end{array}$ & $\begin{array}{c}-0.056 \\
(0.108)\end{array}$ & $\begin{array}{c}0.004 \\
(0.061)\end{array}$ & & & \\
\hline LD. GDP growth & & & & $\begin{array}{c}-0.102 \\
(0.154)\end{array}$ & $\begin{array}{c}-0.139 \\
(0.150)\end{array}$ & $\begin{array}{c}-0.027 \\
(0.113)\end{array}$ \\
\hline L2D. GDP growth & & & & $\begin{array}{c}-0.053 \\
(0.062)\end{array}$ & $\begin{array}{c}-0.060 \\
(0.073)\end{array}$ & $\begin{array}{c}-0.104 \\
(0.054)^{*}\end{array}$ \\
\hline D. Days to start a business & $\begin{array}{c}-0.012 \\
(0.008)\end{array}$ & $\begin{array}{c}-0.004 \\
(0.014)\end{array}$ & $\begin{array}{c}-0.005 \\
(0.008)\end{array}$ & $\begin{array}{c}-0.000 \\
(0.010)\end{array}$ & $\begin{array}{c}0.012 \\
(0.012)\end{array}$ & $\begin{array}{c}0.002 \\
(0.009)\end{array}$ \\
\hline D. Days to enforce a contract & $\begin{array}{c}-0.001 \\
(0.003)\end{array}$ & $\begin{array}{c}0.001 \\
(0.002)\end{array}$ & $\begin{array}{c}0.001 \\
(0.003)\end{array}$ & $\begin{array}{c}-0.004 \\
(0.004)\end{array}$ & $\begin{array}{c}-0.008 \\
(0.004)^{*}\end{array}$ & $\begin{array}{c}-0.006 \\
(0.002)^{*}\end{array}$ \\
\hline D. Labor laws rigidity index & $\begin{array}{c}-0.021 \\
(0.023)\end{array}$ & $\begin{array}{c}0.017 \\
(0.036)\end{array}$ & $\begin{array}{c}-0.019 \\
(0.023)\end{array}$ & $\begin{array}{c}-0.038 \\
(0.040)\end{array}$ & $\begin{array}{c}-0.005 \\
(0.018)\end{array}$ & $\begin{array}{c}-0.030 \\
(0.027)\end{array}$ \\
\hline D. Days to register property & & $\begin{array}{c}0.003 \\
(0.022)\end{array}$ & & & $\begin{array}{c}0.000 \\
(0.030)\end{array}$ & \\
\hline D. Days to export a container & & $\begin{array}{c}-0.031 \\
(0.032)\end{array}$ & & & $\begin{array}{c}0.005 \\
(0.019)\end{array}$ & \\
\hline D. Cost to export a container & & $\begin{array}{c}0.473 \\
(0.649)\end{array}$ & & & $\begin{array}{c}0.236 \\
(0.498)\end{array}$ & \\
\hline LD. Days to start a business & & & $\begin{array}{c}0.003 \\
(0.009)\end{array}$ & & & $\begin{array}{c}-0.002 \\
(0.009)\end{array}$ \\
\hline LD. Days to enforce a contract & & & $\begin{array}{c}-0.003 \\
(0.005)\end{array}$ & & & $\begin{array}{c}-0.004 \\
(0.005)\end{array}$ \\
\hline LD. Labor laws rigidity index & & & $\begin{array}{c}0.001 \\
(0.088)\end{array}$ & & & $\begin{array}{c}0.074 \\
(0.060)\end{array}$ \\
\hline Controls & $\mathrm{Y}$ & $\mathrm{Y}$ & $\mathrm{Y}$ & $\mathrm{Y}$ & $\mathrm{Y}$ & $\mathrm{Y}$ \\
\hline & & 37 & & & & \\
\hline
\end{tabular}

Benjamin P. Eifert. 2009. "Do Regulatory Reforms Stimulate Investment and Growth? Evidince from the Doing Business Data, 2003-07." CGD Working Paper 159. Washington, D.C.: Center for Global Development. http://www.cgdev.org/content/publications/detail/1420894 


\begin{tabular}{lccc|ccc} 
Years & 5 & 3 & 5 & 5 & 3 & 5 \\
Observations & 320 & 139 & 226 & 320 & 139 & 226 \\
Countries & 94 & 81 & 91 & 94 & 81 & 91 \\
\hline
\end{tabular}

Notes: Arellano-Bond estimator of [4] with two lags. Reform coefficients not sensitive to choice of lags or exclusion of control variables. Reform coefficients similar if included one at a time to reduce multicollinearity. Coefficients on import procedures similar to those on export procedures due to high correlation.

Figure 3. Nonparametric estimates of responses to reform 

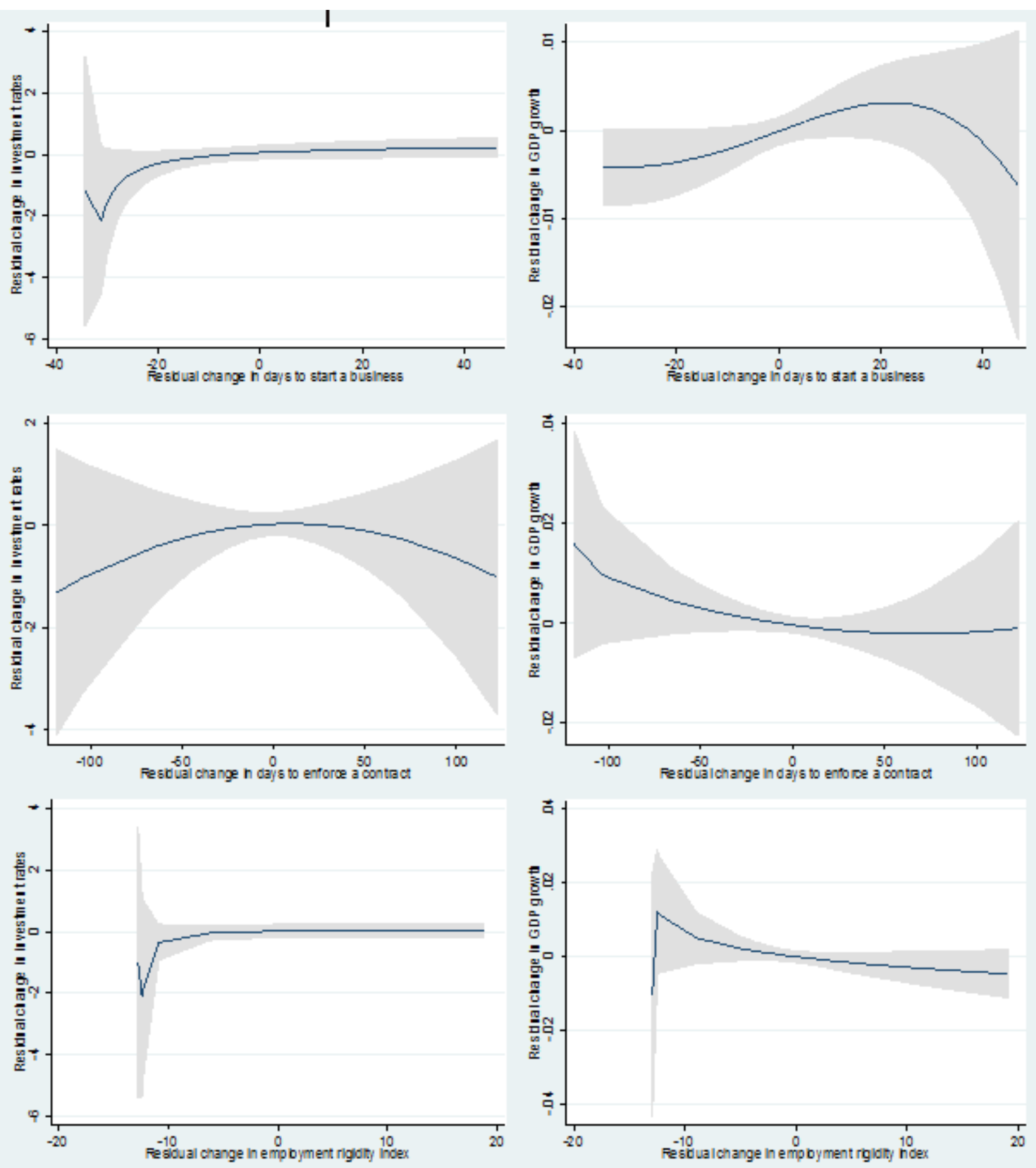
Table 8. Is there a measurable investment response in some subset of countries?

\begin{tabular}{|c|c|c|c|c|c|c|}
\hline & Poorer & Richer & $\begin{array}{c}\text { Worse } \\
\text { policies }\end{array}$ & $\begin{array}{c}\text { Better } \\
\text { policies }\end{array}$ & $\begin{array}{c}\text { Less } \\
\text { open }\end{array}$ & $\begin{array}{l}\text { More } \\
\text { open }\end{array}$ \\
\hline D. Days to start a business & $\begin{array}{c}-0.030 \\
(0.016)^{*}\end{array}$ & $\begin{array}{c}0.002 \\
(0.010)\end{array}$ & $\begin{array}{c}-0.005 \\
(0.008)\end{array}$ & $\begin{array}{c}-0.027 \\
(0.013)^{* *}\end{array}$ & $\begin{array}{c}-0.014 \\
(0.008)^{*}\end{array}$ & $\begin{array}{c}-0.011 \\
(0.019)\end{array}$ \\
\hline D. Days to enforce a contract & $\begin{array}{c}0.001 \\
(0.010)\end{array}$ & $\begin{array}{c}-0.001 \\
(0.003)\end{array}$ & $\begin{array}{c}-0.002 \\
(0.004)\end{array}$ & $\begin{array}{c}-0.002 \\
(0.006)\end{array}$ & $\begin{array}{c}-0.003 \\
(0.003)\end{array}$ & $\begin{array}{c}0.011 \\
(0.008)\end{array}$ \\
\hline D. Labor laws rigidity index & $\begin{array}{c}-0.030 \\
(0.027)\end{array}$ & $\begin{array}{c}-0.016 \\
(0.061)\end{array}$ & $\begin{array}{c}-0.030 \\
(0.033)\end{array}$ & $\begin{array}{c}-0.007 \\
(0.033)\end{array}$ & $\begin{array}{c}0.010 \\
(0.025)\end{array}$ & $\begin{array}{c}-0.166 \\
(0.118)\end{array}$ \\
\hline Controls & Y & Y & Y & Y & Y & Y \\
\hline Observations & 136 & 184 & 175 & 145 & 203 & 117 \\
\hline Countries & 39 & 59 & 55 & 55 & 65 & 41 \\
\hline
\end{tabular}

Notes: each pair of columns splits the sample above and below the median value of the indicator in question (per capita income, ICRG, imports + exports as a share of GDP) after partialing out the other indicators.

Table 9. Is there a measurable productivity response in some subset of countries?

\begin{tabular}{|c|c|c|c|c|c|c|}
\hline & Poorer & Richer & $\begin{array}{c}\text { Worse } \\
\text { policies }\end{array}$ & $\begin{array}{c}\text { Better } \\
\text { policies }\end{array}$ & $\begin{array}{l}\text { Less } \\
\text { open }\end{array}$ & $\begin{array}{l}\text { More } \\
\text { open }\end{array}$ \\
\hline D. Days to start a business & $\begin{array}{c}-0.036 \\
(0.013)^{* *}\end{array}$ & $\begin{array}{c}0.012 \\
(0.011)\end{array}$ & $\begin{array}{c}0.001 \\
(0.009)\end{array}$ & $\begin{array}{c}-0.012 \\
(0.016)\end{array}$ & $\begin{array}{c}-0.003 \\
(0.009)\end{array}$ & $\begin{array}{c}-0.007 \\
(0.017)\end{array}$ \\
\hline D. Days to enforce a contract & $\begin{array}{c}-0.013 \\
(0.007)^{*}\end{array}$ & $\begin{array}{c}0.000 \\
(0.003)\end{array}$ & $\begin{array}{c}0.003 \\
(0.003)\end{array}$ & $\begin{array}{c}-0.015 \\
(0.006)^{*}\end{array}$ & $\begin{array}{c}-0.013 \\
(0.007)^{*}\end{array}$ & $\begin{array}{c}-0.010 \\
(0.008)\end{array}$ \\
\hline D. Labor laws rigidity index & $\begin{array}{c}0.042 \\
(0.028)\end{array}$ & $\begin{array}{c}-0.006 \\
(0.057)\end{array}$ & $\begin{array}{c}0.002 \\
(0.027)\end{array}$ & $\begin{array}{c}0.041 \\
(0.035)\end{array}$ & $\begin{array}{c}0.010 \\
(0.022)\end{array}$ & $\begin{array}{c}0.114 \\
(0.109)\end{array}$ \\
\hline Controls & Y & Y & Y & Y & Y & Y \\
\hline Observations & 155 & 165 & 163 & 157 & 203 & 117 \\
\hline Countries & 39 & 59 & 55 & 55 & 65 & 41 \\
\hline
\end{tabular}

Notes: each pair of columns splits the sample above and below the median value of the indicator in question (per capita income, ICRG, imports + exports as a share of GDP) after partialing out the other two indicators. 
Table 10. Average residual change in macroeconomic outcomes, by reform category -Top pane: contemporaneous reforms. Bottom pane: lagged reforms.

\begin{tabular}{|c|c|c|c|c|c|}
\hline Countries & Category & $N(i)$ & $N(g)$ & $\begin{array}{c}\text { Investment rate } \\
(\%)\end{array}$ & $\begin{array}{c}\text { Growth rate } \\
(\%)\end{array}$ \\
\hline \multirow{3}{*}{ All } & No reforms & 214 & 241 & $0.03[0.17]$ & $-0.06[0.12]$ \\
\hline & $\begin{array}{l}\text { One or more } \\
\text { reform }\end{array}$ & 114 & 131 & $-0.02[0.21]$ & $0.17[0.15]$ \\
\hline & Difference & 328 & 372 & $-0.06[0.13]$ & $0.23[0.12]$ \\
\hline \multirow{3}{*}{ Relatively poor } & No reforms & 103 & 104 & $-0.15[0.28]$ & $-0.39[0.18]$ \\
\hline & $\begin{array}{l}\text { One or more } \\
\text { reform }\end{array}$ & 54 & 54 & $0.06[0.32]$ & $0.47[0.27]$ \\
\hline & Difference & 157 & 158 & $+0.20[0.46]$ & $+0.62[0.32]^{* *}$ \\
\hline \multirow{3}{*}{$\begin{array}{l}\text { Relatively good } \\
\text { policies }\end{array}$} & No reforms & 112 & 112 & $-0.18[0.25]$ & $-0.46[0.18]$ \\
\hline & $\begin{array}{l}\text { One or more } \\
\text { reform }\end{array}$ & 51 & 51 & $-0.08[0.32]$ & $0.11[0.25]$ \\
\hline & Difference & 163 & 163 & $+0.10[0.43]$ & $+0.57[0.31]^{*}$ \\
\hline \multirow[t]{2}{*}{ Countries } & Category & $\mathbf{N}(\mathbf{i})$ & $N(g)$ & $\begin{array}{c}\text { Investment rate } \\
(\%)\end{array}$ & $\begin{array}{c}\text { Growth rate } \\
(\%) \\
\end{array}$ \\
\hline & No reforms & 148 & 176 & $-0.14[0.17]$ & $-0.015[0.13]$ \\
\hline \multirow[t]{2}{*}{ All } & $\begin{array}{l}\text { One or more } \\
\text { reform }\end{array}$ & 80 & 93 & 0.38 [0.29] & $0.004[0.11]$ \\
\hline & Difference & 228 & 269 & $+0.52[0.31]^{*}$ & $+0.008[0.11]$ \\
\hline \multirow{3}{*}{ Relatively poor } & No reforms & 67 & 68 & $-0.42[0.26]$ & $-0.38[0.21]$ \\
\hline & $\begin{array}{l}\text { One or more } \\
\text { reform }\end{array}$ & 41 & 41 & $0.04[0.36]$ & $0.06[0.35]$ \\
\hline & Difference & 108 & 109 & $+0.81[0.44]^{*}$ & $+0.44[0.39]$ \\
\hline Relatively good & No reforms & 73 & 99 & $-0.38[0.23]$ & $-0.38[0.15]$ \\
\hline
\end{tabular}




\begin{tabular}{llcccc}
\hline policies & $\begin{array}{l}\text { One or more } \\
\text { reform }\end{array}$ & 40 & 53 & $0.14[0.35]$ & $-0.17[0.30]$ \\
& Difference & $\mathbf{1 1 3}$ & $\mathbf{1 5 2}$ & $\boldsymbol{+} \mathbf{0 . 5 3 [ 0 . 4 1 ]}$ & $\boldsymbol{+ \boldsymbol { 0 . 2 1 } [ 0 . 3 0 ]}$ \\
\hline
\end{tabular}

*Unit of observation is the country-year. Standard errors are in brackets. 


\section{Conclusions}

This paper studies the impact of regulatory reform on investment rates (roughly, factor demand) and economic growth rates conditional on investment (roughly, factor productivity) over the period 2003-07. It does so using only within-country variation in regulatory indicators and using estimators which take into account macroeconomic dynamics. The basic empirical findings are:

1. Over the period 2003-07, regulatory reforms were not concentrated in countries which were also significantly improving their broader policy environments (as measured by ICRG ratings) or their political environments (as measured by Freedom House scores). Rather, reform incidence was higher in countries with relatively high initial levels of regulation.

2. There is little or no evidence in the full sample of countries for significant economic responses to changes in the costs and administrative delays associated with business registration, contract enforcement, property registration and import/export procedures, nor to reforms of labor regulations.

3. There is some fairly robust evidence of positive impacts of regulatory reforms in countries which are relatively poor (conditional on governance) and relatively well-governed (conditional on income). These estimated impacts are sizeable but not implausibly large. For instance, the median reform of business registration procedures reduces delays by 10 days, and in relatively well-governed countries is associated with an increase in investment rates of 0.27 percentage points.

4. Comparing countries which reform in at least one area in a given year to those which do not, relatively poor and relatively well-governed countries grow significantly faster (conditional on their investment rates) in reform years, about 0.4 and 0.2 percentage points faster, respectively. In both subsets of countries, investment rates accelerate significantly in the year after a reform, by about 0.6 percentage points relative to non-reformers.

Taken together, these results suggest general optimism about the prospects for improved economic performance in reformist countries in the developing world, especially those which are relatively better-governed. This set includes China and India, which contain a large proportion of the world's poor, and India in particular has been an active reformer. It also includes several African countries 
which have performed well over the last decade, including Ghana, Tanzania and Uganda. While we cannot rule out the possibility that governments tend to introduce unobserved economy-boosting measures in the same years as they make specific observed regulatory reforms, biasing the coefficient estimates above upward, one might expect such a pattern to lead to a correlation between reform incidence and the trajectory of ICRG scores in particular.

Another cautionary note is the discrepancy in the results for business registration and contract enforcement procedures on the one hand and labor laws on the other. It seems unintuitive that labor regulations - which increase the variable costs of large, high-productivity firms - should have no estimated impact on macroeconomic aggregates, while business registration procedures which create fixed entry costs and hence screen out mostly low-productivity firms have a significant impact. In the present author's view, one would be well-advised to remain optimistic about the broader reform agenda while not emphasizing point estimates on individual regulatory indicators too heavily. Moving forward, building on the positive results in Bruhn (2006) and Kaplan, Piedra \& Siera (2007), microeconomic research on entrepreneurship, income generation and poverty reduction may be the most promising way forward. 


\section{References}

Bentolila, S., \& Bertola, G. (1990). Firing Costs and Labor Demand: How Bad is Eurosclerosis? The Review of Economic Studies , 57 (3), 381-402.

Bertrand, M., \& Kramarz, F. (2002, November). Does Entry Regulation Hinder Job Creation? Evidence from the French Retail Sector. The Quarterly Journal of Economics , 1369-1413.

Bertrand, M., Djankov, S., Hanna, r., \& Mullainathan, S. (2006). Obtaining a Driver's License in India: An Experimental Approach to Studying Corruption. forthcoming, Quarterly Journal of Economics.

Besley, T., \& Burgess, R. (2004). Can Labor Regulation Hinder Economic Performance? Evidence from India. Quarterly Journal of Economics , 119 (1), 91-134.

Blanchard, O. (2004). The Economic Future of Europe. Journal of Economic Perspectives , 18 (4), 326.

Botero, J., Djankov, S., La Porta, R., \& Lopez de Silanes, F. (2004). The Regulation of Labor. Quarterly Journal of Economics , 119 (4), 1339-1382.

Bruhn, Miriam (2006), "License to Sell: The Effect of Business Registration Reform on Entrepreneurial Activity in Mexico," unpublished paper, MIT.

Conway, P., Janod, V., \& Nicoletti, G. (2005). Product Market Regulation in OECD Countries, 19982003. Paris: OECD Economics Department Working Paper \#419.

Cooper, R., \& Haltiwanger, J. (2006). On The Nature of the Capital Adjustment Costs. Review of Economic Studies , 73 (3).

Cooper, R., \& Willis, J. (2003). The Economics of Labor Adjustment: Mind the Gap. Federal Reserve Bank of Kansas City, Research Working Paper 03-05.

Desai, M., Gompers, P., \& Lerner, J. (2003). Institutions, Capital Constraints and Entrepreneurial Firm Dynamics. NBER working paper \#w10165.

Dixit, A., \& Stiglitz, J. (1977). Monopolistic Competition and Optimum Product Diversity. The American Economic Review , 67 (3), 297-308.

Djankov, S.; McLiesh, C.; Ramalho, R. (2006), “Regulation and Growth,” Economics Letters 92

Djankov, S., La Porta, R., \& Lopez de Silanes, F. (2003). Courts. Quarterly Journal of Economics , 118, 457-522. 
Djankov, S., La Porta, R., Lopez de Silanes, F., \& Shleifer, A. (2002). The Regulation of Entry. Quarterly Journal of Economics , 117, 1-37.

Djankov, Simeon.; Hart, Oliver; McLiesh, Caralee; Shleifer, Andrei (forthcoming), “Debt Enforcement Around the World," Journal of Political Economy.

Fallon, P. R., \& Lucas, R. E. (1993). Job Security Regulations and the Dynamic Demand for Industrial Labor in India and Zimbabwe. Journal of Development Economics , 40, 241-275.

Hasan, R., Mitra, D., \& Ramaswamy, K. (2003). Trade Reforms, Labor Regulations and Labor Demand Elasticities: Empirical Evidence from India. NBER working paper \#9879.

Hopenhayn, H. (1992). Entry, Exit and Firm Dynamics in Long Run Equilibrium. Econometrica , 60 (5), 1127-1150.

Jayaratne, J., \& Strahan, P. (1998). Entry Restrictions, Industry Evolution and Dynamic Efficiency: Evidence from Commercial Banking. Journal of Law and Economics , 41, 239-273.

Joyanovic, B. (1982). Selection and the Evolution of Industry. Econometrica, 50 (3), 649-670.

Kaufmann, D., \& Kraay, A. (2005). Governance Matters IV: Governance Indicators for 1996-2004. World Bank working paper .

Laffont, J.-J. (2005). Regulation and Development. Cambridge: Cambridge University Press.

MacIsaac, D., \& Rama, M. (1997). Determinants of Hourly Earnings in Ecuador: The Role of Labor Market Regulations. Journal of Labor Economics , 15 (3), 136-165.

McKenzie, D., \& Woodruff, C. (2006). Do Entry Costs Provide an Empirical Basis for Poverty Traps? Evidence from Mexican Microenterprises. Economic Development and Cultural Change , 55, 3-42.

Messina. (2002). Sectoral Structure and Entry Regulations. European Central Bank, working paper.

Nickell, S. (1997). Unemployment and Labor Market Rigidities: Europe versus North America. The Journal of Economic Perspectives , 11 (3), 55-74.

Pakes, A., \& Ericson, R. (1998). Empirical Implications of Alternative Models of Firm Dynamics. Journal of Economic Theory, 79, 1-45.

Rajan, R., \& Zingales, L. (1998). Financial Dependence and Growth. The American Economic Review, $88,559-586$.

Scarpetta, S., Hemmings, P., Tressel, T., \& Woo, J. (2002). The Role of Policy and Institutions for Productivity and Firm Dynamics: Evidence from Micro and Industry Data. OECD Economics Department working paper \#329.

Benjamin P. Eifert. 2009. "Do Regulatory Reforms Stimulate Investment and Growth? Evidince from the Doing Business Data, 2003-07." CGD Working Paper 159. Washington, D.C.: Center for Global Development. http://www.cgdev.org/content/publications/detail/1420894 
Viviano, E. (2006). Entry Regulations and Labour Market Outcomes: Evidence from the Italian Retail Trade Sector. Bank of Italy Economics Research Department, working paper.

Winston, C. (1998). U.S. Industry Adjustment to Economic Deregulation. Journal of Economic Perspectives , 12 (3), 89-110.

World Bank. (2007). Doing Business 2007. Washington, D.C. 